Mikołaj Nkollo* and Alexandra Fiéis

\title{
The não interpolation in Classical and early Modern European Portuguese and the mapping between syntactic and phonological structures: An empirical study
}

\author{
https://doi.org/10.1515/shll-2020-2023
}

\begin{abstract}
The central topic of the paper is clitic-verb non-adjacency (interpolation) in Classical and early Modern European Portuguese (EP). Throughout that period, the negative marker não was the only expression likely to disrupt the continuity of clitic-verb sequences. The aims of the study are twofold. First, previous assumptions on the syntax of this pattern are matched against data retrieved from the texts stored in the Biblioteca Nacional Digital. The present analysis demonstrates, first, that clitic-verb adjacency and non-adjacency had divergent distributions depending on whether they occurred in obligatory proclisis contexts or in $\mathrm{X}-\mathrm{V}-\mathrm{cl} / \mathrm{X}-\mathrm{cl}-\mathrm{V}$ variation ones. Whereas interpolation was the default choice in the former, clitic-verb adjacency was prevailing in the latter in the period under discussion. The second aim is to account for the overrepresentation, underpinned by corpus data, of 3rd person accusative pronouns in clauses with interpolation. In previous works, the origin of clitic-verb nonadjacency was couched either in semantic terms (the contribution of não to the meaning of the VP) or in terms of clitic movement and increasing constraints on the status of Neg (Neg and clitic are both assumed to be affixes). In the present paper, interpolation is shown to have had an interface nature, with phonological factors playing a central role. The discontinuity of clitic-Verb sequences is thought to have helped speakers to get rid of the affixal attachment of the $o, a$, os, as series to the preceding non-verbal sound material (nasal diphthongs in não, quem, ninguém, etc, coercing preverbal pronouns into taking a nasal onset quem no, não no, etc.). As a consequence, in present day standard $\mathrm{EP}$, clitic-specific allomorphy has become earmarked for enclisis.
\end{abstract}

Keywords: European Portuguese, interpolation-inducing contexts, affixal attachment, 3rd person accusative pronouns, negative marker

\footnotetext{
*Corresponding author: Mikotaj Nkollo, Adam Mickiewicz University, Faculty of Modern Languages, Poznań, Poland, E-mail: mikon74@amu.edu.pl Alexandra Fiéis, CLUNL/FCSH - Universidade NOVA de Lisboa, Lisbon, Portugal, E-mail: afieis@fcsh.unl.pt
} 


\section{Introduction}

The present paper is devoted to the interpolation of não in Classical and early Modern European Portuguese (EP). The time frame of the phenomenon brought under investigation is enclosed between the early seventeenth and the midnineteenth centuries, a period when the negative marker was the sole element disrupting the continuity of clitic-verb sequences. The results are underpinned by an inquiry into corpus-based language material. Thus, instead of tracing anew the history of interpolation, the analysis draws attention to several distributional facts that have gone unnoticed thus far.

More precisely, the aims pursued here are twofold. First, some of the previous findings on the syntax of interpolation in Classical Portuguese are challenged, arising as a by-product of the observation of corpus data. The second aim is to propose an alternative approach to Clitic-Verb non-adjacency in Classical and early Modern EP. ${ }^{1}$ The issue has thus far received explanations formulated in predominantly syntactic terms. Moreover, the interpolation of não has frequently been conceived of as a transitional phase between two other stages of the development of the Portuguese clitic system: Old Portuguese and Modern Portuguese (Martins 2016: 422-423). In what follows, substantial evidence is presented in favor of an alternative view. It is going to be argued that clitic-Verb non-adjacency in Classical Portuguese had an original, multi-faceted character with phonological factors having also played a prominent role.

The paper is organized as follows: in Section 2, a historical sketch of EP interpolation is outlined alongside some of the previous findings where varying constraints on the nature of expressions eligible to be inserted between a clitic pronoun and the verb are traced back to clitic movement. In Section 3, the principles underlying the preparation of our corpus are discussed. Besides raising technical issues inherent in corpus linguistics, this part ascertains in what respects it is different from previously compiled corpora. Section 4

1 Proposals on how the history of EP should be chronologically sliced have been formulated by various authors. According to Castro (2006: 158-166, 188-194), there are four periods: i) Old Portuguese (from the first text published in 1214 to approx. 1420); (ii) Middle Portuguese (from 1420 to 1550); (iii) Classical Portuguese (from 1550 to the late 1700s); and (iv) Modern Portuguese (from approx. 1800 onwards). By contrast, in syntactically based accounts (Namiuti 2008: 22-24), periods in the history of EP are defined on a strictly grammatical basis. As a result, three phases, rather than four, are singled out: Old Portuguese (up to approx. 1450), Classical Portuguese (1450 1700) and Modern EP (from approx. 1700 onwards). The results of our analyses do not coincide in all respects with syntactically based divisions of how particular clitic placements distributed over history. Therefore, in what follows we subscribe to the traditional chronology. 
pinpoints syntactic conditions in which interpolation materialized or failed to do so. Accordingly, the concept of 'interpolation-inducing context' is introduced as a prerequisite to a thorough calculation of frequencies, and a rigorous delineation of the scope of the phenomenon. The results of our corpus analysis are indicative of the divergent distributions of clitic-Verb adjacency and nonadjacency across two major syntactic patterns: obligatory proclisis contexts and proclisis vs. enclisis variation contexts (the latter inherent to Classical Portuguese, and generally reanalyzed as part of obligatory enclisis contexts afterwards). Whereas interpolation used to be the default option in the former set of contexts, it was marked in the latter. In Section 5, mechanisms underlying the prevalence of third-person accusative pronouns in clauses with the interpolation of não are inquired into. Unlike the remaining clitics, $o, a$, os, as were subject to frequent mergers in the preverbal domain. Although the mergers were most widespread in Old Portuguese, they have never become definitely extinguished ever since. The não negative, alongside several other proclisis-triggers ending in a nasal diphthong, was likely to alter the form of the ensuing accusative pronouns even in Classical Portuguese texts. Clitic-verb non-adjacency is demonstrated to have acted, then, as an allomorphy-preventing device in such configurations. Section 6 summarizes the discussion over the mechanisms that prompted the interplay of clitic-Verb adjacency and non-adjacency in the period under discussion. Concluding remarks are presented in Section 7.

\section{Interpolation in the history of EP}

Clitic placement in EP has been the subject of many studies, both synchronically and diachronically, but there is no general consensus in what concerns the explanation for the proclisis-enclisis variation. Depending on the author, clitic placement in EP may be triggered by properties of the high peripheral functional domain (e. g. Madeira 1992; Martins 1994; among others), by specific proclisis triggers (e. g. Duarte and Matos 2000), or by syntactic and prosodic factors (e. g. Barbosa 1996; Frota and Vigário 1996). In fact, there are several theoretical proposals to account for clitic placement in EP, but, since our main goal is the interpolation of não, we will refrain from detailing these analyses here.

Additionally, and at first glance, inquiring into the interpolation of não in Classical Portuguese may seem an inauspicious task. Martins (1994: 307-308), for instances, has claimed that variation between clitic-verb adjacency/nonadjacency at that period was no more than a result of authors' individual choices. Indeed, the diversity of idiolectal attitudes cannot be automatically 
equated with an ongoing grammatical change (Stark 2013: 149, 166-167). Thus, rather than providing reliable clues to the emergence of a novel clitic grammar, the interpolation of não in the texts released between seventeenth and nineteenth centuries has been conceived of as a transitional state. Its single role consisted in acting as a bridge between two divergent clitic grammars, with interpolation being treated differently in each of them. One involves an indiscriminate interpolation that used to pervade Old and Middle Portuguese writings. The other is the present-day 'deictic' and dialectally circumscribed interpolation that came into being in the thirties of the nineteenth century. Its frequency has been drastically undermined ever since. Furthermore, interpolation of não is still acceptable as a grammatical option in EP (cf. Duarte 2003: 866-867), although subject to individual variation.

Clitic-verb non-adjacency is a long-standing linear pattern, with its first attestations dating back to as early as the thirteenth century, i. e. to the very beginning of EP scriptural tradition (Fiéis 2001; Martins 1994). In the Middle Ages, constituents separating the clitic pronoun and the verb were virtually unrestricted as to their nature, number and length (Martins 2016: 421). ${ }^{2}$ Yet, even in spite of this rampant freedom, it was the não negative marker that outnumbered by far any other type of items. After having delved into Medieval and Renaissance legal documents, Martins (2016: 422-423) established the following figures for the interpolation of não in clauses with proclisis triggers different from não itself: 13th c. $-94,1 \%$; 14th c. $-96,8 \%$; 15th c. $-90,7 \%$; 16th c. $-90 \%$. Therefore, this syntactic pattern must be considered unmarked throughout that period. Another archaic property, i. e. the lack of restrictions on the number of interpolated constituents, is tantamount to saying that multiple interpolations are documented in Old Portuguese as well. Even so, the ordering of juxtaposed constituents was not entirely random. If a subject was one of the elements of a series, it tended to be inserted first, i. e. directly after the clitic pronoun (Fiéis 2001: 205-207). Conversely, if a negative marker was part of a sequence of interpolated elements, it always surfaced at the end, i. e. directly before the verb (Raposo 2000: 278-279). This stage of Portuguese clitic system is known as 'generalized interpolation.'

In syntactic terms, generalized interpolation corresponds to the first of the three stages singled out in the history of Portuguese clitic grammar. It is reported

2 According to Martins, in Medieval Portuguese, any constituent not belonging to the left periphery of the sentence can occur between the proclitic and the verb (Martins 2016: 422 '... qualquer constituinte que possa ocorrer à esquerda do verbo e que não esteja topicalizado nem focalizado (i. e. que não pertença à periferia esquerda da frase) pode ser interpolado entre o clítico e o verbo no português medieval.' 
to have become obsolete in the sixteenth century (Namiuti 2008: 7). In Namiuti's (2008) proposal, generalized interpolation is accounted for in terms of clitic movement: the clitic pronoun is allowed to move to $\mathrm{C}$ in subordinate clauses, whereas the Verb moves up to $\Sigma$. Once the clitic is moved, a variety of XPs separate it from its default verbal host. That is how the generalized clitic-verb non-adjacency (with any kind of expressions allowed to follow the pronoun and precede the verb), including multiple interpolations, comes about. ${ }^{3}$ Clitic movement to $\mathrm{C}$ is associated with the dominance of the $\mathrm{C}$-cl-(X)-negV word order, one of the salient features of which consists in the contiguity of proclisis triggers and clitic pronouns. Under this analysis, however, V-to-C movement prevails, which is consistent with the author's claim that both Old and Classical Portuguese were V2-like languages.

Along different lines, another syntactically based explanation for this positional freedom is couched in terms of IP scrambling. ${ }^{4}$ According to this viewpoint, Old (and Middle) Portuguese featured intersecting lines within syntactic trees. SOV word orders were more frequent as a result of IP middle scrambling (e. g. raising to multiple Spec, TP positions; Martins 2002), and not of movement to the C domain. Certain expressions were likely to appear either at a distance ('scrambled'; see Costa and Martins 2010: 59-61; Martins 2011a: 139-140) from their heads or, alternatively, fixed orders were missing for some dependent - head groups. For example, both 'predicate adjective - copula' and 'copula - predicate adjective' orders were allowed. Once scrambling had been lost, indiscriminate interpolation began to recede (Martins 2014: 42-44). ${ }^{5}$

This grammar was being gradually superseded by a newer one, where restrictions on movement prevented clitics from occurring higher than in $\Sigma^{6}{ }^{6}$ The latter constituent, posited for languages with preverbal negative markers, stands for an

3 After an analysis conducted in Fernão Lopes's chronicles, Andrade and Namiuti-Temponi (2016: 213) demonstrate that XP interpolation appears in response to the information status of the preverbal XP: the more topical a given constituent is, the more it is likely to surface verbadjacently.

4 Since the main goal of our study is to account for the interpolation of não, we will refrain from adopting either analysis of cliticization.

5 Interpolation is indicative of the distinction between the OV orders brought about by the presence of contrastive foci or marked topics and the OV orders with scrambled objects, since clitics mark the border between the sentence left periphery and the middle field (Martins 2002, Martins 2011a: 140-141).

6 The functional category $\Sigma$ (Sigma) (from Laka 1990) is associated with the expression of sentential polarity (Negation, Affirmation and Modality), and is projected between C and I. It plays a crucial role in the derivation of enclisis in finite clauses in Portuguese (its strong-V features being responsible for the Verb moving further to $\Sigma$, leaving the clitic in the inflectional domain) (cf. Martins 1994, Martins 2002, Martins 2005, among other works). 
assemblage of the verb and the não negative. Negative markers are incorporated (NB. in so doing, they behave syntactically as clitics; cf. Andrade and NamiutiTemponi 2016: 204 '... Neg interpolation is the natural output from the syntax, clitic and Neg behaving as syntactic clitics to the verb'; in line with; Matos 1999: 187-188) into any expressions within their scope that are checked for Tense, thereby producing sentential negation. This grammatical profile is found in Classical Portuguese and seems to be definitely fixed by the mid-seventeenth century. The ' $\mathrm{C}$-X-clnegV' word order gains ground in dependent clauses. According to Namiuti (2008: 13), increasing constraints on clitic movement would, at once, shed light on a multitude of phenomena of that period: the loss of the generalized interpolation, the rise of proclisis at the expense of enclisis, and the decrease of 'proclisis trigger - clitic adjacency.' Finally, reduced mobility of clitics is thought to have been responsible also for the presence of nãointerpolation in enclisis vs. proclisis variation contexts (in root clauses).

Obviously, early seventeenth century texts are a playground for two competing grammars. No systematic dividing lines have been found between e. $g$. literary and non-literary texts. Authors either complied with the old grammar or limited themselves to interpolate no constituent but não. This grammar is going to be paid special attention in the following sections.

As for interpolation in Modern EP, its origin is traced back to restrictions upon the preverbal field where subjects became the only type of constituents allowed. Verbs do not rise to $\Sigma$ any longer. Instead, they become confined into I. Presentday interpolation is different from its predecessors in that a) não is not the only eligible expression, although its frequency exceeds the frequency of the remaining constituents; b) unlike in Medieval and Classical Portuguese, it is semantically constrained. As demonstrated by Magro (2010a: 107-108), outside of the negative marker, only deixis carriers are inserted between the pronoun and the verb. 'Deixis-carrier' stands here for time, space or person-related linguistic signs, irrespective of their nature - NPs, adverbs and adverbials (e.g. prepositional phrases), small clauses, or strong pronouns (Magro 2010b: 121). Additionally, interpolated units may encode aspect or modality, i. e. speaker's behavioral stance towards the propositional content. Likewise, multiple interpolations have regained their position, although limited to short, deictic constituents. ${ }^{7}$ This is

7 In C. Magro's approach (2010b: 127-130), present-day dialectal interpolation appears to be the result of a post-syntactic process that is more superficial than IP scrambling found in Old Portuguese. The [+ deictic] feature triggers a [Copy/Delete] metathetic process (Harris and Halle 2005: 199-201). It affects two contiguous segments that are required to be otherwise interrelated. Two steps are involved: first, the segments are repeated, and their outermost elements are deleted upon Vocabulary Insertion. For example, in Se eu o soubesse 'If I had known it,' the eu 
illustrated in our corpus with the following examples (page numbers given in particular examples refer to BND's files, not to the book-internal numbering).

a. $E$ o que vos

eu dizia aqui be.PRS.IND.3.SG DEM.M.SG REL DAT.2.PL I say.IPFV.IND.1.SG here 'This is what I was talking to you about here' (1842. Almeida Garrett, $O$ alfageme de Santarém ou a espada do Condestável ... IV, 5; p. 98) purl.pt/53

b. Agora porem que até a minha pobre now however that even ART.DEF.F.SG POSS.1.F.SG poor $\begin{array}{lllll}\text { bibliotheca } & \text { já } & \text { se } & \text { ahi } & \text { vai } \\ \text { library } & \text { already } & \text { REFL.3 } & \text { here=DIST } & \text { go.AUX.3.SG } \\ \text { rareando } & & e & \text { desfazendo vendida } \\ \text { become-rarer.PRS.PTCP } & \text { and } & \text { undo.PRS.PTCP } & \text { sell.PST.PTCP.F.SG }\end{array}$ 'Still, at present when even my poor library is vanishing, taken apart by being sold off'(1837. António Feliciano de Castilho, A Primavera; p. 11) purl.pt/29

Aside from having changed its grammatical properties, today's interpolation has lost much of its former momentum. Curiously, corpus-based evidence shows that the modern phase was flourishing in literary production of the 1830s and the following decades. From that period on, its frequency has been constantly dwindling, until interpolation became no more than a fraction of instances of clitic-verb adjacency in today's standard EP. In the meantime, its sociolinguistic profile has changed accordingly. While it is poorly attested in current literary works, dialectal spoken production provides a favorable locus for its occurrences (Magro 2010a: 106-107; Martins 2016: 423). In terms of acceptability judgements, interpolation is subject to variation in present-day EP. The não negative marker is given priority over deictics (but cf. Duarte 2003: 833 who says that não is the only linguistic sign likely to occur between a clitic pronoun and the verbal host).

Curiously, although it covers approximately 200 years in the history of EP, the interpolation of não has thus far been described as rather unappealing. An opinion going along these lines has been, yet in a civil way, expressed by A. M. Martins 'não há nenhuma evolução a registar' (Martins 1994: 308), i. e. no grammatical change affecting interpolation is recorded from the sixteenth

and $o$ arguments are reduplicated, provisionally producing Se [eu o eu o] soubesse. After the deletion of the left- and right-edge segments of the sequence [eu o eu $\theta$ ], metathesis is being produced. 
through the nineteenth centuries. Nevertheless, the interpolation of mere não still poses some challenging questions regarding both its frequency and contexts of occurrence (namely, the opposition between root and embedded clauses, obligatory proclisis vs. variation contexts). For all those reasons, there is still room for a corpus study on interpolation. Obviously, a representative sample of linguistic data is an essential prerequisite to successfully conducting even such a modest study.

\section{The corpus}

Our corpus has been compiled from 49 texts (both continuous excerpts and integral versions) released between 1614 and 1858. Their complete lists are given alongside references. The texts are of various sizes, ranging from a modicum of 37 clitic-verb sequences in the anonymous text Noticia certa das grandes vitorias que os austriacos alcançaram contra os prussianos na Silezia (1758) to 2073 sequences in the compendium by Pedro Norberto de Aucourt e Padilha (1759; see references). They represent different genres (exclusive of poetry), displaying a multitude of styles and degrees of formality. The texts target various groups of addressees (or even single addressees) and had been composed in a variety of communicative circumstances by individuals of varying social rank and education. The latter characteristics can be easily inferred from the degree of lexical refinement and grammatical correctness of the writings in the corpus. As for the customary selection criteria, an obvious, yet unintentional, gap is related to the absence of female authors. Although some of the texts are anonymous, no serious evidence supports the idea of their female authorship (see e.g. Donaldson 2014: 334-338 for a case study of how gender variation may inform syntax). Women-authored texts are few and far between in the period under discussion. Furthermore, the selection of seventeenth-century and nineteenthcentury works has been narrowed down so that the não negative marker would be the only element eligible to break the continuity of clitic-verb sequences. The intent was to filter out the texts that represent either Old-Middle or Contemporary EP clitic grammar.

Yet, in two cases, the corpus deviates from the last criterion. The first exception is the chronicle by Bento Teixeira Feio (born in 1605, that is in the time frame selected for the corpus), released as late as in 1650. In the fragment looked into (BND's file pages 5-47), it contains no multiple interpolations. Apart from $n a \tilde{o}$, the only two violations of the integrity of clitic-verb sequences rely on simple lexical units, bem 'well' and melhor 'better.' 


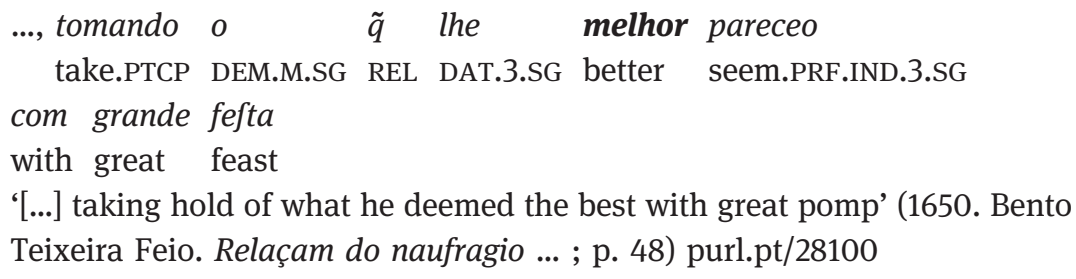

The point is that in many of the earlier seventeenth-century texts, the não interpolation had already been exclusive (no other elements intervened between a clitic pronoun and the verb). That is why Texeira Feio's text has eventually been included in the corpus. For that and also due to the goals of this text, we have ignored the examples with other types of interpolation besides não.

Namiuti (2008) considers this kind of 'shaky' grammars to be the result of how individual speakers come to grips with diglossia. In her opinion:

... uma vez que uma comunidade se torna diglóssica com relação a uma dada fixação paramétrica, os falantes poderiam aprender ambos os parâmetros, e a escolha de qual critério de boa formação que deva ser aplicado na produção de uma dada instância de fala recairia no domínio da performance (2008: 18-19) 'Once a given speech community becomes diglossic with respect to the fixation of a given parameter, speakers can acquire both parameters; if they are left with the decision as to which rule of well-formedness should apply in a given speech event, the choice would be a matter of performance.' (our translation)

Even if two old-style interpolations are present, they look odd amid a wealth of interpolations carried out exclusively with the aid of não. Although the author may have spent his youth being exposed to a certain number of cues for an antiquated clitic grammar, the interpolation of melhor and bem may as well represent his deliberate decision to permeate his scriptural production with archaic features. ${ }^{8}$ Be that as it may, the fact that only two interpolations

8 Therefore, accounts of how an ongoing grammatical change actually proceeds in a given speech community must not be automatically mapped onto an idiolectal level. Aside from a change conceived of as 'a random walk through the space of possible combinations of parameter settings' (Battye and Roberts 1995: 11), a given grammatical pattern, especially if it occurs isolated, leaves room for individual user's fanciful decisions. The idea is nimbly exposed by Namiuti (2008: 85): "A busca por certo rebuscamento, na imitação dos antigos misturada ao vernáculo e às leituras acumuladas podem gerar estruturas agramaticais na escrita." 'The quest for some degree of refinement in an attempt to imitate the Classics, mixed up with vernacular linguistic habits and a heap of past readings may generate a faulty grammar in writing.' 
deviating from the classical pattern are present is not at odds with the pervasiveness of não in clitic-verb non-adjacency, i. e. the model inherent to Classical Portuguese.

The second exception is the Horrorosa mortandade, a report on criminal events with a follow-up political commentary. The text, whose author is known only by initials as A.J.F.G., was published in 1834. His story is particular in that it contains one case where clitic-verb non-adjacency is due to the insertion of cá 'here.' All of the remaining interpolations rely on não. Thus, the text is illustrative of an incipient phase of modern-style interpolation, with an increasing presence of 'deictic' expressions eligible to separate the pronoun and the verb. This model was to become mass-reproduced in literary production in years to come (see examples 1a-b above), which is consonant with how Magro localizes the beginning of the modern interpolation in EP.

$$
\begin{aligned}
& \text {...; pois todo o mundo sabe } \begin{array}{l}
\text { que } \\
\text { Thus } \\
\text { cá cherybody know.PRS.IND.3.SG COMP }
\end{array} \text { who.REL } \\
& \text { ACC.3.M.PL } \\
& \text { here call.PRF.IND.3.SG be.PRF.IND.3.SG ART.DEF.F.SG high.F.SG politics } \\
& \text { 'So, everybody realizes that it was high politics that had attracted them } \\
& \text { here' (1834. A.J.F.G. Horrorosa mortandade ...; p. 19) purl.pt/31011 }
\end{aligned}
$$

At present, the number of all recorded clitic-verb combinations in all of the texts spanning 244 years is 14.553 . All of them have been manually retrieved and annotated. The reason is that the files stored in the Biblioteca Nacional Digital are not editable and no automatic search is likely to be conducted (the same holds true for the text of A. Vieira's letters, the source of which is Brazil-based, i. e. Biblioteca Brasiliana Guita e José Mindlin; digital.bbm.usp.br/handle/bbm/ 4527). The corpus contains 948 examples of interpolation-inducing contexts. The term, which is vital to the present investigation (see below), extends over the presence of não in both obligatory proclisis contexts and in contexts where enclisis and proclisis were freely interchangeable in Classical Portuguese, and where enclisis is nowadays mandatory. In both of these structural environments, não is either verb-adjacent or not. The three exceptional sequences mentioned above - with melhor, bem and cá - have been left out of the statistics. The choice between clitic-verb adjacency and non-adjacency covers nearly $6.5 \%$ of all instances of clisis. The results summarized in Table 1 point to a noticeable unevenness between the 1600 s and the subsequent centuries, even if interpolation kept its privileged status throughout.

Finally, it is worth comparing our BND-based data with linguistic material retrieved from the previously existing corpora, to see in what respects they are 
Table 1: Chronological frequency of interpolation compared to clitic-verb adjacency.

\begin{tabular}{lrrrr}
\hline & $\begin{array}{r}\text { Sequences } \\
\text { with clitics }\end{array}$ & $\begin{array}{r}\text { Interpolation- } \\
\text { inducing } \\
\text { contexts }\end{array}$ & $\begin{array}{r}\text { non-adjacency } \\
\text { vs. adjacency }\end{array}$ & $\begin{array}{r}\text { frequency of clitic- } \\
\text { verb non-adjacency } \\
\text { (percent) }\end{array}$ \\
\hline $\begin{array}{l}\text { Seventeenth century } \\
(13 \text { texts) }\end{array}$ & 4.397 & 348 & $257: 91$ & $73.85 \%$ \\
$\begin{array}{l}\text { Eighteenth century } \\
(20 \text { texts) }\end{array}$ & 5.895 & 324 & $194: 130$ & $59.87 \%$ \\
$\begin{array}{l}\text { Nineteenth century } \\
(16 \text { texts })\end{array}$ & 4.261 & 276 & $142: 134$ & $51.44 \%$ \\
Total (49 texts) & 14.553 & 948 & $593: 355$ & $62.55 \%$ \\
\hline
\end{tabular}

original, or, alternatively, merely replicate other scholars' work. Among them, the Tycho Brahe Parsed Corpus of Historical Portuguese (TBC; 3,302,696 words; Galves et al. 2017) stands out as most thoroughly worked out. As for the period where não was the sole interpolated linguistic sign, the TBC offers several dozens of texts. Therefore, it became the source of data for a substantial number of research papers devoted, among others, to the evolution of Portuguese clitic grammar (Sandalo and Galves 2013: 128-129). The texts in the corpus in question have been assorted using, somewhat inconsistently, the criterion of authors' date of birth, rather than the date of the publication of their texts (Galves 2018: 52). ${ }^{9}$ Curiously, this methodological bias does not prevent anonymous writings from becoming part of the TBC. Indeed, as far as EP is concerned, some of the texts, subsumed under the 'Various' label, were compiled on the basis of Gazeta de Lisboa (eighteenth century) and seventeenth-century 'clumsily handwritten notes' (Manuscritos das Mãos Inábeis) by unidentified authors. No analogous constraint has been imposed onto the data retrieved from the BND. This decision might have some bearing on the results exposed in the present study.

A significant number of our examples have been drawn from anonymous press releases (or, as far as the eighteenth century is concerned, small unsigned

9 This decision corresponds to the view, associated with the work of David Lightfoot (2006), that syntactic changes come about only during language acquisition. They originate from individual cues available to new generations of speakers that compute a large-scale grammatical system on the basis of parent's speech. The change boils, then, down to a series of microscale transitions between synchronically stable individual grammars (see Kroch 2001: 708-710). The principal mechanism prompting the change is the devious imitation of older generation's grammatical habits. As parents' internalized grammar is not directly available to new generations of learners, its reconstruction must be flawed to some point (the situation is known as 'imperfect transmission of linguistic attitudes'). 
brochures reporting on current military events in Europe and Asia). As the stories they describe are only slightly prior to the date of publication, it is probable that no significant (spanning several generations) time lag is found between the year of issue of a given title and the date of birth of the author. Furthermore, in the nineteenth century in particular, some of the periodicals became platforms of heated political debates over the drawbacks of the monarchy in Portugal. Appeals were launched and arguments were exchanged back and forth, frequently with the use of rhetorical devices intended to boost their powers of persuasion. These appeals involved, among others, serial repetitions of negative interrogative sentences or conditionals juxtaposing multiple negated protases, each of which depicted an undesirable situation, subsequently paired with a paradoxical conclusion in the apodosis. All of them appear to be associated to a pragmatic implicature (strong suggestion of a positive answer, as in Haven't you ever study Latin?; cf. Larrivée 2017: 455). Moreover, some of these strategies are apparently influenced by the 'priming effect,' i. e. a tendency to replicate linguistic material or grammatical patterns used in the preceding stretches of the same text (Blas Arroyo and Schulte 2017: 23). This discourse architecture, even if not exclusive to anonymous press texts, is apparently favored by the argumentative character of the political appeals of that period. ${ }^{10}$ Whether these specific clausal types implied more frequently the usage of não interpolation calls, of course, for further elucidaton. A convenient example is quoted in (4).

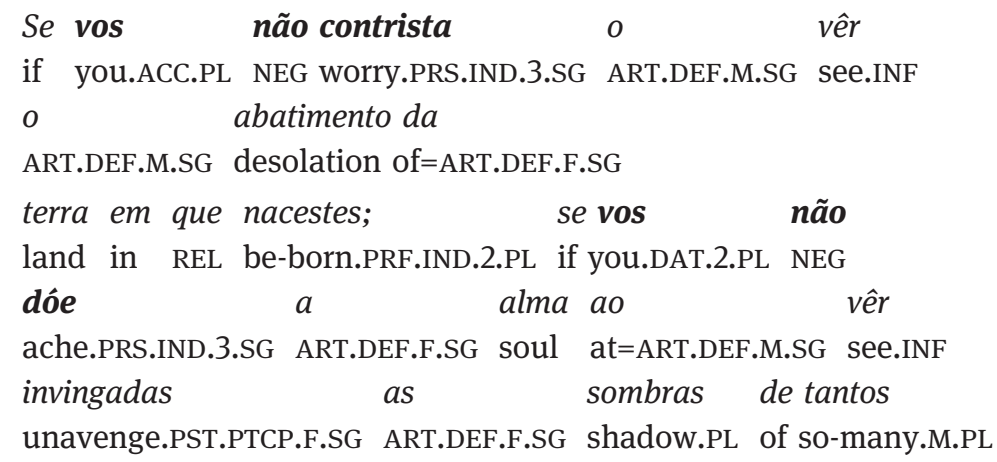

10 This stylistically motivated figure is, in some respects, comparable to the construal of sentences in Vieira's Sermons, extensively characterized by Galves et al. (2005: 54-56). The stylistic artifices in Vieira's text result in an elevated ratio of enclisis in XV sentences, including subjects in the $\mathrm{X}$ position. Yet, a closer inspection reveals that $\mathrm{X}$ in these sequences are contrastive topics, thus having a clause-external status. Enclisis appears, then, to represent a side-effect of the Tobler-Mussafia constraint. Discursively, this upsurge of (X-)V-cl sentences is traced back to the baroque oratory style in which lexical oppositions between extraposed constituents are a frequent structural and rhetorical device. 


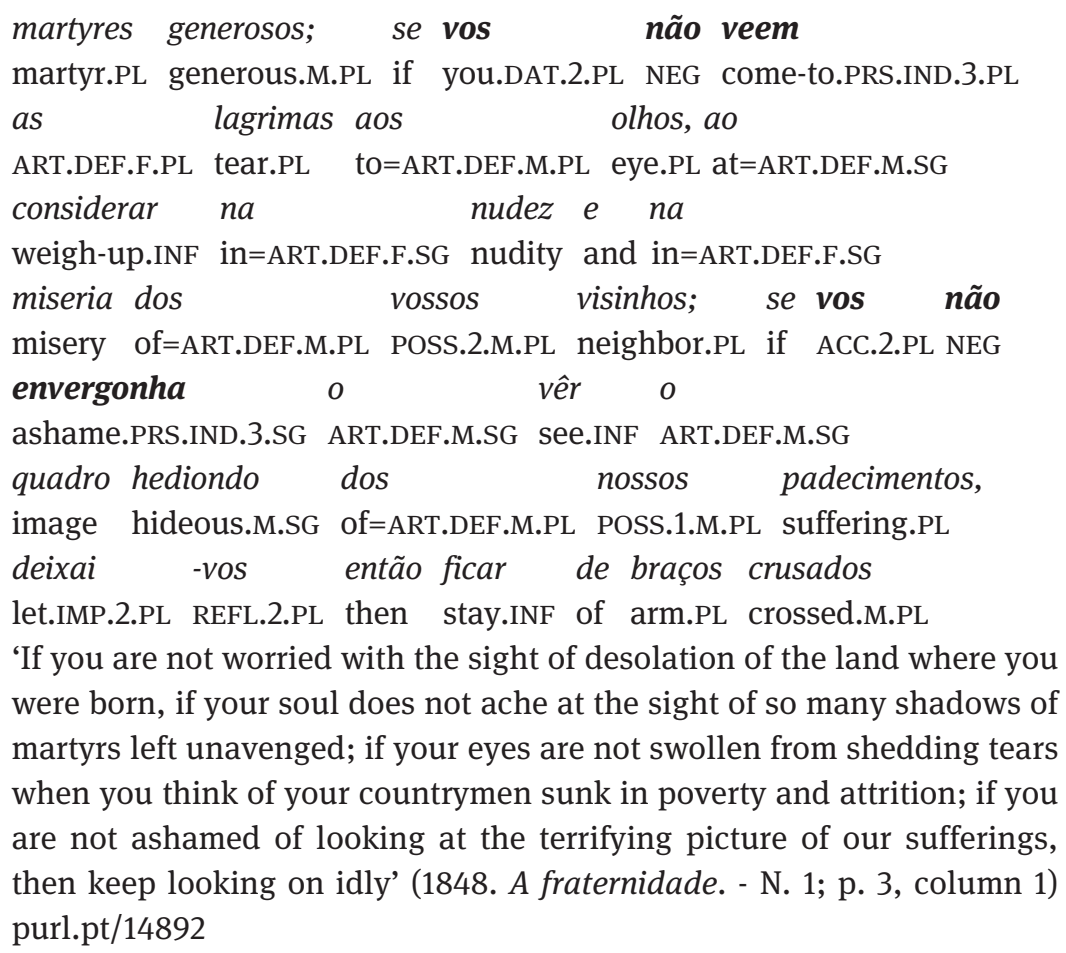

To ascertain whether and to what extent the two corpora might be qualitatively different, an overview of the distribution of clitics in a randomly selected TBC text, absent in our corpus, has been carried out. The Cartas, a series of epistolary writings by Cavaleiro de Oliveira (born 1704), have been chosen. Its original edition dates back to 1741, thus having been close to the heart of the period which is the central concern of the present investigation.

In the overwhelming majority of the texts retrieved from our BND corpus clitic-verb non-adjacency brought about by the não negative outnumbers adjacency in obligatory proclisis contexts, ${ }^{11}$ and the TBC text does not contradict this tendency (Table 2).

The curious thing about the results retrieved from the Cartas is the pervasiveness of clitic-verb non-adjacency in interpolation-inducing contexts with a proclisis trigger. The frequency of this pattern, reaching almost $90 \%$, is similar

11 A thorough analysis of the data retrieved from the BND corpus will be presented in the following sections. Nonetheless, the present comparison is meant to show that, although both corpora might be qualitatively different mainly due to the more informal style of Cavaleiro de Oliveiras's Cartas, the BND is representative of the grammar of the period under discussion. 
Table 2: The distribution of pronouns and the ratio of clitic-verb non-adjacency to adjacency in the Cartas (1741) in obligatory proclisis contexts.

\begin{tabular}{lrrrr}
\hline & cl-não-V & não-cl-V & Percent & Ratio \\
\hline se & 49 & 4 & 92.45 & $12.25: 1$ \\
me & 25 & 7 & 78.125 & $3.57: 1$ \\
o, a, os, as & 24 & 2 & 92.3 & $12: 1$ \\
vos & 15 & 2 & 88.23 & $7.5: 1$ \\
lhe, lhes & 13 & & 100 & \\
te & 2 & & 100 & \\
nos & 2 & 1 & 66.66 & $2: 1$ \\
clusters & 2 & & 100 & \\
Total & 132 & 16 & 89.18 & $8.25: 1$ \\
\hline
\end{tabular}

to the position it used to have in the Middle Ages. Another original feature of the TBC's text is the complete lack of clitic-verb adjacency with lhe/lhes dative forms. Apparently, this result has to be blamed on the insufficient size of the micro-corpus. Likewise, the results in the Cartas depart from the BND-based corpus in the extent to which the se reflexive tends to precede the negative marker.

Yet, in other respects, clitic grammar documented in de Oliveira's letters is similar to the findings achieved with the aid of the BND texts. For example, both sources converge with respect to the interpolation of não outside obligatory proclisis contexts, as highlighted in Tables 3 and 5 below. The Cartas contain four occurrences, thus being noticeably inferior to clitic-verb adjacency with 23 hits achieved (cf. 5a-b). A similar distribution is found in BND's texts. Likewise, as highlighted further below, the frequencies of particular types of clitic pronouns in both sources are coincident.

Table 3: The distribution of pronouns and the ratios of clitic-verb adjacency to non-adjacency in the Cartas (1741) in X-V-cl/X-cl-V variation contexts.

\begin{tabular}{lrrrr}
\hline & não-cl-V & cl-não-V & Percent & Ratio \\
\hline se & 14 & 1 & 93.33 & $14: 1$ \\
o, a, os, as & 3 & 2 & 60 & $1.5: 1$ \\
me & 4 & & 100 & \\
lhe, lhes & 1 & & 100 & \\
nos & 1 & 1 & 100 & \\
vos & & & 0 & \\
clusters & & & & \\
te & 23 & 4 & 85.18 & $5.75: 1$ \\
Total & & & & \\
\hline
\end{tabular}


a. $A$

virtude sincera $\quad$ e $a$

integridade

ART.DEF.F.SG virtue sincere.F.SG and ART.DEF.F.SG integrity

perfeita de que ele se orna o

perfect.F.SG of REL he.SBJ REFL.3.SG adorn.PRS.IND.3.SG ACC.3.M.SG

não encaminhavam a desconfiar dos meus

NEG lead.IPFV.IND.3.SG to distrust.INF of=ART.DEF.M.PL POSS.1.PL

artifícios

artifice.PL

'the sincere virtue and the perfect honesty he adorns himself with were not leading him to beware my artifices' (Letter 31. À senhora Condessa de Roccaberti. Com a notícia dos amores de Filandro e de Aspásia; p. 145; 0-5)

b. A vossa intenção não se pode

ART POSS.2.PL intention NEG REFL.3.SG can.PRS.IND.3.SG

descobrir, ...

discover.INF

'Your intention cannot be revealed' (Letter 42. Ao senhor F. Tasso Diaxo, a respeito do estilo e dos seus escritos, p. 198; 15-20)

\section{Interpolation-inducing contexts}

As announced above, 'interpolation-inducing contexts' were the principal type of combinations looked for after the corpus had been compiled. An attempt to list exhaustively lexical and syntactic contexts relevant for both the generalized interpolation and não interpolation was undertaken by Martins (1994: 183-185). The following inventory of contexts is detailed in her work: subordinate clauses with a finite verb form, subordinate clauses with an infinitive introduced by de, a, por, pera, and em, root clauses headed by proclisis-inducing adverbs, quantifiers (including negative ones) and focused constituents. All of them correspond to obligatory proclisis contexts (cf. Martins 1994: 186 "Devemos então concluir que a interpolação ocorre quando o clítico, para além de ter colocação pré-verbal, tem-na necessariamente" 'We are led, then, to conclude that interpolation takes place if a clitic, aside from being preverbal, occupies this position obligatorily'). She adds (1994: 190) that the negative marker não, despite being a proclisis trigger, does not induce interpolation. As it stands directly next to the verb, it has no scope over the preceding clitic pronouns. ${ }^{12}$ Hence, the order 'não-cl-X-V' is never attested (Martins, idem).

12 Years after, Hinzelin (2010) approached the problem with the aid of the concept of exordium. According to him, the prerequisite for interpolation is a special sign preceding both a clitic 
Namiuti (2008) extends the list so that clitic-verb non-adjacency is likely to occur after omitted complementizers, in dependent coordinate conjuncts (even if the complementizer fails to recur; in which she repeats Martins 1994: 184) and after 'explicative' conjunctions. Indeed, BND's data provide confirmation of such configurations. In the example (6a), the complementizer (spelled ' $\tilde{\mathrm{q}}$ ') has scope over each of the two coordinate clauses (conjoined by a sign spelled ' $\&$ '). The second conjunct, where an overtly expressed complementizer is missing, is a clitic-não-verb sequence. In (6b), the que complementizer is simply dispensed with altogether. All such cases are subsumed here under obligatory proclisis contexts. An alternative stance would require the structure of such sentences to be treated in terms of parataxis, or juxtaposition of two root clauses. It is the frequent presence of the subjunctive after null complementizers that provides the main piece of evidence against the analysis couched in terms of parataxis, as the mood is known to be lexically selected by the main verb.

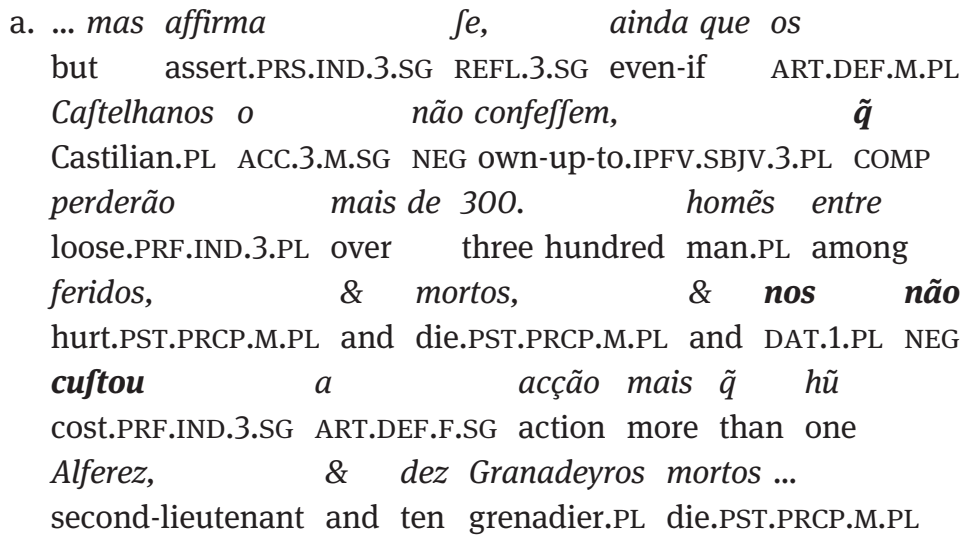

pronoun and the não negative marker (cf. 'L'exordium est un élément introducteur tel que le complémenteur, pronom relatif, pronom interrogatif, etc. dont la présence s'impose pour que l'interpolation soit admise'). This is to say that only if an exordium is present, can não disrupt the continuity of clitic-verb sequences. Mandatory exordia prevent clitics from appearing in an absolute sentence-initial position ( ${ }^{\star} O$ não sei). Hinzelin (2010: 336) adds two elements to the original list: relative and interrogative pronouns. This reasoning relies on the assumption that if proclisis and the interpolation of não might have been applied interchangeably, and if proclisis must be triggered in present-day EP, so must it have been with interpolation. Seemingly, in this proposal, constraints on clitic placement are somewhat unwarily projected from present-day EP onto Classical Portuguese grammar. Hinzelin's list partially overlaps with Duarte and Matos' (2000: 117-120) repertoire of operator-like elements c-commanding the verbal host of the clitic. All of them coerce clitic pronouns into occurring preverbally. 
'But it is reported, although the Spaniards do not own up to it, that they lost over three hundred people killed and wounded and that the skirmish cost us no more than a second lieutenant and ten grenadiers killed' (1714. Anonymous. Relaçam da campanha de Alemtejo ...; p. 31)

b. ..., cõ proteftos, lhe foi requerido

with protest.PL DAT.3.SG be.PRF.IND.3.SG require.PST.PTCP.M.SG

o não fizeffe ...

ACC.M.3.SG NEG do.IPFV.SBJV.3.SG

'With protests he was requested not to do that' (1644. Anonymous. Relaçam em que se refere parte dos gloriosos successos, ...; p. 3) purl. $\mathrm{pt} / 12510$

All in all, the statistics for interpolation vs. clitic-verb adjacency in obligatory proclisis contexts are as shown in Table 4.

Table 4: Chronological frequency of interpolation compared to clitic-verb adjacency (obligatory proclisis contexts only) in the BND-corpus.

\begin{tabular}{lrrr}
\hline & $\begin{array}{r}\text { Interpolation-inducing } \\
\text { contexts (obligatory } \\
\text { proclisis contexts) }\end{array}$ & $\begin{array}{r}\text { non-adjacency } \\
\text { vs. adjacency }\end{array}$ & $\begin{array}{r}\text { frequency of clitic- } \\
\text { verb non-adjacency } \\
\text { (percent) }\end{array}$ \\
\hline Seventeenth century & 286 & $242: 44$ & $84.61 \%$ \\
Eighteenth century & 268 & $182: 86$ & $67.91 \%$ \\
Nineteenth century & 202 & $139: 63$ & $68.81 \%$ \\
Total & 756 & $563: 193$ & $74.47 \%$ \\
\hline
\end{tabular}

Still, in Classical and early Modern Portuguese the interpolation of não was allowed outside obligatory proclisis contexts as well, ${ }^{13}$ when compared to the interpolation of other constituents (cf. Martins 1994; Namiuti 2006: 173, 2008), thus pointing to the insufficiency of the lists of exordia in defining syntactic criteria for clitic-verb non-adjacency. Interestingly, if in the period under discussion interpolation attains the average of $74,47 \%$ in BND's clauses containing

13 Namiuti (2008: 143-149) singles out five cases of this type. All of them correspond to proclisis vs. enclisis variation contexts. In line with the constraints referred to above, in none of the models is the não negative allowed to be sentence-initial. The five contexts comprise: (a) clauses headed by an overtly expressed preverbal subject; (b) clauses headed by a prepositional phrase; (c) V1 clauses preceded by a subordinate clause; (d) clauses headed by X (adverb or non-argumental prepositional phrase); (e) V1 clauses headed by a coordinate conjunction. 
a proclisis trigger (Table 4), it becomes scaled down to cover merely 15,62\% of cases in root clauses allowing for a free-choice use of either enclisis or proclisis (Table 5). Moreover, in proclisis vs. enclisis variation contexts, adjacency evinces a systematic increase until becoming nearly exclusive in the early nineteenth century.

Table 5: Adjacency vs. non-adjacency in X-V-cl vs. X-cl-V variation contexts (root clauses only) in the BND-corpus.

\begin{tabular}{lrrr}
\hline & $\begin{array}{r}\text { Interpolation-inducing } \\
\text { contexts (enclisis/proclisis } \\
\text { variation contexts) }\end{array}$ & $\begin{array}{r}\text { adjacency vs. } \\
\text { non-adjacency }\end{array}$ & $\begin{array}{r}\text { frequency of clitic- } \\
\text { verb adjacency } \\
\text { (percent) }\end{array}$ \\
\hline Seventeenth century & 62 & $47: 15$ & $75.8 \%$ \\
Eighteenth century & 56 & $44: 12$ & $78.57 \%$ \\
Nineteenth century & 74 & $71: 3$ & $95.94 \%$ \\
Total & 192 & $162: 30$ & $84.37 \%$ \\
\hline
\end{tabular}

The calculations effectuated in the BND corpus (Table 5) show that the presence of clitic-verb non-adjacency in the BND's eighteenth-century texts in these specific contexts $(21,42 \%)$ is only slightly inferior to its presence in the texts dating from the 1600 s $(24,2 \%)$, thereby disconfirming the pace of the evolution advocated in TBC-inspired analyses. It remains to be investigated whether this difference reflects the fact that the time-frame in the TBC corpus takes the authors' year of birth in consideration, whereby the changes would have occurred about 50 years before those noticed in corpora based on the date of publication of the texts. For example, Namiuti (2008: 53) notes that:

Vemos que X-cl-neg-V é produtivo na época em que a próclise é dominante na língua. Justamente nos primeiros anos dos 1700 notamos o início da generalização da ênclise com $X$ - $V$ e a concomitante queda (e desaparecimento) da interpolação da negação no mesmo tipo de contexto. 'We can see that $\mathrm{X}-\mathrm{cl}-\mathrm{neg}-\mathrm{V}$ is productive at the period where proclisis is dominant in the grammar. Starting from the beginning of the 1700s, the rise of enclisis in $\mathrm{X}-\mathrm{V}$ sequences becomes conspicuous. The phenomenon is intertwined with the decrease (and an eventual collapse) of the não-interpolation in this context.'

Varying judgements are issued on the exact set of syntactic positions hosting non-triggered não interpolation (see Martins 2016: 416; Namiuti 2008). In the present paper, it is going to be admitted that fluctuations were found in five of them: (i) V1 root clauses following a subordinate clause; (ii) V1 clausal conjuncts introduced by coordinating conjunctions $e$ 'and,' mas 'but,' pois 'then' (Hinzelin 2007: 32-33, 35); (iii) clitic left-dislocation (CLLD), with a resumptive clitic 
pronoun following the topicalized constituent; (iv) root clauses with an overtly expressed preverbal subject; (v) root clauses with preverbal adverbs and nonargumental PPs.

Galves et al. (2005: 42-43) demonstrate that a further bipartition is needed in these syntactic configurations. The point is that clitic placement shows divergent evolutions in each of the two sub-groups they single out. Variation contexts 1 extend over affirmative, syntactically independent clauses in which $\mathrm{cl}-\mathrm{V} / \mathrm{V}$-cl sequence is preceded by referential, non-quantified and not overtly focalized subjects, adverbs (other than fronted VP adverbs) and prepositional phrases (PPs), provided the latter are not arguments. Therefore, examples such as (7) are left out of the analysis.

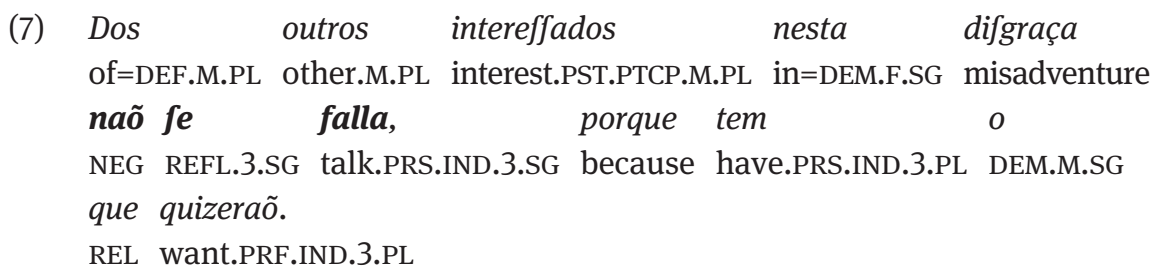

'The other involved in this misadventure are not being dwelt on any longer, because they get what they wanted' (1735. Antonio Vieira. Carta CXV: Ao Marquès de Gouvea; p. 422) digital.bbm.usp.br/handle/bbm/4527

Variation contexts 2 extend over V1 coordinates following the conjunction and V1 root clauses with fronted subordinate clauses (thus, no CLLD sequences have been retained as separate syntactic constructions). ${ }^{14}$ Proclisis appears to have been gradually receding in these particular syntactic environments from as early as the beginning of the eighteenth century.

Indeed, in none of the five contexts singled out below is proclisis syntactically induced (there is no proclisis trigger). ${ }^{15}$

14 A thorough analysis of data available in the TBC demonstrates that the likelihood of enclisis in the second set of contexts is positively correlated with the length of a preceding clause (Galves et al. 2005: 51, 61). If it consists of at least eight phonological words, the clitic pronoun almost unmistakably follows the verb in the root clause. As for the first set of contexts, a turning point, coincident with the beginning of the eighteenth century, has been discovered. Up to that period, a free-choice clitic placement is posited as a grammatical parameter. From that period on, variation is upheld only as one of the possible outcomes of two competing grammars: an outdated one with a parametric enclisis / proclisis interchangeability and a modern one, where enclisis is the default option in $\mathrm{X}-\mathrm{V}$ affirmative sentences. This finding has an extensive corpus-based corroboration. 15 Another interpretation is that in some of the CLLD sequences, the preverbal constituent may function as a proclisis trigger. 
(I) V1 (verb first) root clauses following a subordinate clause

a. ...; e causando isto admiraçaõ a todos, and cause.PRS.PTCP DEM amazement to all.M.PL

lhe perguntaraõ alguns ...

DAT.3.SG ask.PRF.IND.3.PL some.M.PL

'Everyone being astonished at that, some of them asked him' (1761. Irmaõ Amador do Dezengano. Espelho critico, no qual claramente se vem alguns defeitos das mulheres, ...; p. 4) purl.pt/22744

b. ..., finda

a converfa, perguntou-

finish.PST.PTCP.F.SG ART.DEF.F.SG coversation ask.PRF.IND.3.SG lhe dita Senhora com vangloria, DAT.3.SG ART.DEF.F.SG say.PST.PTCP.F.SG lady with vainglory e jactancia:

and proud

'Once the conversation ended, the Lady, full of vainglory and proud, asked him ...' (1761. Irmaõ Amador do Dezengano. ibid.; p. 6)

(II) V1 clausal conjuncts introduced by coordinating conjunctions $e$ 'and,' mas 'but,' pois 'then'

(9)

a. Receberão

suas

communicações, $e$

as

be-given.PRF.IND.3.PL POSS.3.F.PL teaching.PL and ACC.3.F.PL

transmitirão ...

transmit.PRF.IND.3.PL

'They were given their teachings and transmitted them' (1823. Luís da Silva Mousinho de Albuquerque. Ideas sobre o estabelecimento ...; p. 34-35) purl.pt/6412

b. Invocou -se formalmente o auxilio invoke.PRF.IND.3.SG REFL.3.SG formally ART.DEF.M.SG aid do Poder Civil, e deve- se of=ART.DEF.M.SG power civil and must.PRS.IND.3.SG REFL.3.SG reconhecer, que... acknowledge.INF COMP

'Appeal was made to the aid of civic authorities and it has to be admitted that ...' (1832. Guilherme Walton. A expedição de Dom Pedro ...; p. 19) purl. $\mathrm{pt} / 6673$

(III) clitic left-dislocation (CLLD), with a resumptive clitic pronoun following the extraposed constituent 
a. Huma peffoa affaz conhecida na

ART.INDF.F.SG figure fairly know.PST.PTCP.F.SG in=ART.DEF.F.SG

noffa Corte [...], a vimos com efpada

POSS.F.1.PL court ACC.F.3.SG see.PRF.IND.1.PL with sword

à $\quad$ cinta; ...

at=ART.DEF.F.SG belt

'A pretty well known figure at our court, one day we saw her walking with a sword fastened to her belt' (1759. Pedro Norberto de Aucourt e Padilha. Raridades da natureza ... Ch. XXV Hermafroditas; p. 203) purl. $\mathrm{pt} / 13915$

b. ...: efte famofo Capitam depois de ter com muito

dem.M.SG famous.M.SG commander after AUX with much.M.SG

cufto, e muito fangue defbaratado o Exercito

effort and much.M.SG blood defeat.PST.PTCP ART.DEF.M.SG army

de Darîo, e a ele mefmo captivo, vierã̃

of Darius and to him self.M.SG prisoner come.PRF.IND.3.PL

-lhe dizer, que as filhas do

DAT.3.SG tell.INF COMP ART.DEF.F.PL daughter.pl of=ART.DEF.M.SG

vencido lhe pediaõ audiencia.

defeat.PST.PTCP.M.SG DAT.3.SG ask.IPFV.IND.3.PL audience

'after he had defeated in a hard and bloody struggle the army of Darius and made Darius himself his prisoner, this famous commander was told that his opponent's daughters were asking him for an audience' (1761. Espelho critico, ...; p. 11) purl.pt/22744

(IV) root clauses with an overtly expressed preverbal subject

$\begin{array}{rrrr}\text { a. ..., o } & \text { seu } & \text { espirito se } & \text { illustra } \\ \text { ART.DEF.M.SG } & \text { POSS.3.M.SG mind REFL.3.SG excel } \\ \text { com huma } & \text { vasta } & \text { erudição, ... } \\ \text { with } & \text { ART.INDF.F.SG vast } & \text { erudition }\end{array}$

('Apart from outstanding moral qualities that this estimable Minister is endowed with,) he is also a man of great spirit and erudition' (18101811. José Accursio das Neves. Historia geral da invasão dos francezes ... t.I, Ch. XXI; p. 272) purl.pt/12098
b. Este
commissario apresentou
-se
DEM.M.SG officer
introduce.PRF.IND.3.SG REFL.3.SG 
com decreto da nua nomeação

with ART.DEF.M.SG decree of=DEF.F.SG POSS.3.F.SG appointment

'This officer introduced himself handing over the decree of his nomination' (ibid., Ch. XVIII; p. 226)

(V) root clauses headed by an adverbial

(12)

$\begin{array}{llll}\text { a. Daqui } & \text { fegue- } & \text { fe, } & \text { que } \\ \text { from-here } & \text { follow.PRS.IND.3.SG } & \text { REFL.3.SG } & \text { COMP } \\ \text { todas } & \text { as } & \text { fuas } & \text { contraditorias, ... } \\ \text { all.F.PL } & \text { ART.DEF.F.PL } & \text { POSS.3.F.PL } & \text { contradictory.F.PL }\end{array}$

'From where it follows that all of his contradictions ...' (1758. Luís António Verney. Resposta as Reflexoens, ... Reflexam V. Da Gramatica, e Latinidade; p. 25) purl.pt/24753

b. Mas efpecialmente no quarto lhe but especially in=ART.DEF.M.SG fourth.M.SG DAT.3.PL encomenda que eftudem a recommend.PRS.IND.3.SG COMP study.PRS.SBJV.3.PL ART.DEF.F.SG

Retorica

rhetoric

'But especially in the fourth (chapter) he recommends them to study rhetoric' (ibid. Reflexam VI. Da Retorica; p. 32)

Notwithstanding the absence of proclisis triggers, the corpus contains attestations of both interpolation and clitic-verb adjacency in all of these contexts. The distribution of particular classes of clitic pronouns in all of the five variation contexts (see Table 6) shows that interpolation tends to be associated with the accusative series (see Table 7).

Table 6: Clitic-verb adjacency and non-adjacency in the BND corpus in root clauses (X-V-cl/X-cl-V variation contexts).

\begin{tabular}{lrr}
\hline X-V-cl/X-cl-V variation contexts & cl-V adjacency & cl-V non-adjacency \\
\hline Fronted adverbs and non-argumental PPs & 38 & 5 \\
After the preceding subordinate & 42 & 10 \\
After the coordinating conjunction & 28 & 2 \\
CLLD & 4 & 4 \\
Overtly expressed, non-quantified, preverbal subjects & 50 & 9 \\
Total & 162 & 30 \\
\hline
\end{tabular}


Table 7: The distribution of pronouns and the ratio of clitic-verb adjacency to non-adjacency in the BND corpus (1614-1858) in X-V-cl/X-cl-V variation contexts.

\begin{tabular}{lrrrr}
\hline & não-cl-V & cl-não-V & $\begin{array}{r}\text { adjacency } \\
\text { (percent) }\end{array}$ & Ratio \\
\hline se & 84 & 7 & 92.3 & $12: 1$ \\
o, a, os, as & 23 & 16 & 58.97 & $1.43: 1$ \\
me & 26 & 1 & 96.29 & $26: 1$ \\
lhe/lhes & 15 & 4 & 78.94 & $3.75: 1$ \\
clusters & 6 & 1 & 85.17 & $6: 1$ \\
nos & 4 & 1 & 80 & $4: 1$ \\
te & 3 & & 100 & \\
vos & 1 & & 100 & \\
& 162 & 30 & 84.37 & $5.4: 1$ \\
\hline
\end{tabular}

(I) V1 (verb first) root clauses following a subordinate clause

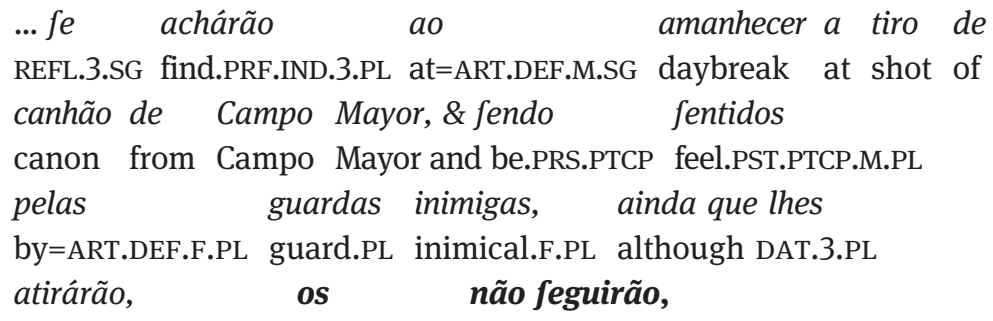

shoot.PRF.IND.3.PL ACC.3.M.PL NEG follow.PRF.IND.3.PL com que puderão recolherfe with REL can.PRF.IND.3.PL shelter.INF=REFL.3.PL

DAT.3.PL shoot.PST.PRF.3.PL ACC.3.M.PL NEG chase.PST.PRF.3.PL

á pequena Praça de Ouguela ... to=ART.DEF.F.SG small.F.SG Praça of Ouguela

'... found themselves at dawn within shooting distance from Campo Mayor, and having been spotted by the enemy, whose sentinels, even if opened fire, did not chase after them, owing to which they were able to find shelter at the small Ouguela square' (1714. Anonymous. Relaçam da campanha de Alem-Tejo no Outono de 1712, com o Diario do sitio, \& gloriosa defensa da praça de Campo Mayor, recopiladas memorias dos Generaes; p. 17) http://purl.pt/26483

(II) V1 clausal conjuncts introduced by coordinating conjunctions $e$ 'and,' mas 'but,' pois 'then' 
(14) $\mathrm{Eu}$ quis reprezentar com todo o

I.SBJ want.PRF.IND.1.SG represent.INF with all.M.SG ART.DEF.M.SG encarecimento a $S . \quad$ Mageftade, [...] e o nã̃ fiz, ... tenderness to your majesty and ACC.M.3.SG NEG do.PRF.IND.1.SG 'I wanted to depict with all the tenderness Your Majesty [...], but I failed to do that' (1735. António Vieira. Carta XVII. Ao Bifpo do Japaõ; pág. 149)

(III) clitic left-dislocation (CLLD)

(15) Todos os que defobedecerem a Meza naõ all.M.PL DEM.M.PL REL disobey.FUT.SBJV.3.PL ART.DEF.F.SG Meza NEG querendo aceitar cargo algum nella fem want.PRS.PTCP accept.INF position no.DET.F.SG in=it.F.SG without cauza, que efta julgue por baftante, reason REL DEM.F.SG consider.PRS.SBJV.3.SG for sufficient, ou fe aceitarem, naõ quizerem pagar as or if accept.FUT.SBJV.3.PL NEG want.FUT.SBJV.3.PL pay.INF ART.DEF.F.PL fuas joyas, e fe fizerem petição para ferem POSS.3.F.PL fee.PL and if make.FUT.SBJV.3.PL petition for be.INF.3.PL admetidos, $\quad a \quad$ Meza os na admit.PST.PTCP.M.PL ART.DEF.F.SG Meza ACC.3.M.PL NEG podera aceitar fem primeiro eftarem por qualquer can.FUT.IND.3.SG accept.INF without prior be.INF.3.PL by any cargo que a Meza lhe der,... position REL ART.DEF.F.SG Meza DAT.3.PL give.FUT.SBJV.3.SG 'All those who oppose themselves to the Board, by refusing for no apparent reason to be in charge of any matters whatsoever, that might be deemed suitable by the Board, or if they accept, but refuse to pay their membership fees, and if they apply for being admitted, the Board will not accept them as long as they do not exercise the function allotted to them by the Board' (1749. Compromisso da irmandade ... Cap. XV; p. 40) purl.pt/24981

(IV) root clauses with an overt non quantified, non focalised preverbal subject ..., e fe fizerem petiçaõ para os admitirem, and if do.FUT.SBJV.3.PL petition for ACC.M.3.PL admit.INF.3.PL a Meza o nã̃ farà fem ART.DEF.F.SG Meza ACC.3.M.SG NEG do.FUT.IND.3.SG without 
pagarem $\quad$ que deverem.

pay.INF.3.PL DEM.M.SG REL owe.FUT.SBJV.3.PL

'... and if they petition for being admitted, the Board will not give their assent until outstanding membership fee is duly paid' (1749. Compromisso da irmandade da Gloriosa Virgem e Martir Santa Cecilia. Cap. XV; p. 40) purl.pt/24981

(V) root clauses headed by an adverbial

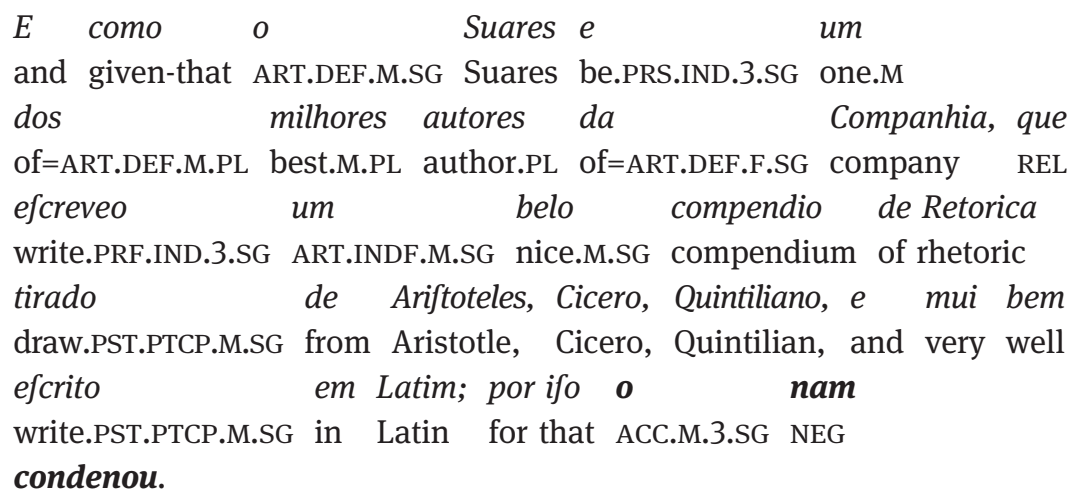

disapprove.PRF.IND.3.SG

'And given that Suares is one of the best authors of the Society (of Jesus), who wrote a nice compendium based on Aristotle, Cicero and Quintilian and which was, moreover, drawn up in very good Latin, therefore, he did not disapprove of it' (1758. Luís António Verney. Resposta as Reflexoens, ... Reflexam VI. Da Retorica; p. 33) purl.pt/24753

As for the fourth of the above contexts, variation hinges neither on how subjects actually surface (proper vs. common noun) nor on whether they are definite or not. Moreover, the corpus contains three occurrences of clitic-não-verb clauses headed by a bare subject pronoun, in two different texts. Two of these occurrences depict a lively conversation in a theatre play (comedy). If, as some scholars assume (Kragh and Schøsler 2015: 267-268), theatre plays are closest to orality, these examples may shed light on the type of communicative circumstances in which interpolation outside obligatory proclisis contexts used to be most persistent. ${ }^{16}$ Some of the

16 It remains to be seen in future research whether the usage of interpolation in theatre plays (taken to be less formal) is more frequent than in the other genres. A cursory observation shows that theatre plays in the period under discussion do not privilege interpolation at a radically higher rate. For instance, in António José da Silva's Vida do grande D. Quixote de La Mancha ... (released in 1759, Parte II, Scenes 2-8), the ratio is 20 to 9 in favor of interpolation in interpolation-inducing contexts. In Manuel de Figueiredo's Escola da Mocidade (complete 
examples show variation involving the same subject pronoun and the same clitic pronoun. ${ }^{17}$ Even more astonishingly, in both of the source texts, aside from subject pronoun-clitic-não-verb sequences, ordinary proclisis is also found, with no selfevident differences deducible.
a. $E u \quad$ o
não creio (Florinda).
I ACC.3.M.SG NEG believe.PRS.IND.1.SG
'I can't believe that' (1804-1810. Manuel de Figueiredo. Escola da Mocidade II, 12; p. 139) purl.pt/11977
b. Eu não o digo (Damiana).
I NEG ACC.3.M.SG say.PRS.IND.1.SG
'I'm not saying that' (ibid. II, 4; p. 123)

Ibero-Romance languages are known to tend to insert subject pronouns with the intent to introduce narrow-scope (or contrastive) foci (Gupton 2014: 141). Contrastive foci, in turn, are classified as proclisis triggers, both in present-day EP and in its past stages (Duarte and Matos 2000: 117-119). Yet, the examples (18a-b) are disconcerting in that in none of them is the discursive function focus ('a resolution for a variable left open in previous discourse,' López 2009: 28) or topic (piece of information, highly predictable and retrievable from the foregoing discourse) - of subject pronouns overtly marked. Therefore, in the first of the above examples o não creio, etc. would have brought about the same semantic effect as eu não o creio does. Correspondingly, no clear-cut dividing line separates the interpolation of não from instances of clitic-verb adjacency in de Figueiredo's play. In the paper by Galves et al. (2005 51-52), sentences with overtly expressed preverbal, referential subjects are subsumed

text), the respective figures are 23 to 10 . Still, Martins (2011b) has shown that the talks of Gil Vicente's popular characters (sixteenth century) already exhibit the 'enclitic' grammar closer to what is found in Contemporary EP. This 'presumably vernacular grammar is closer in important respects to Old Portuguese and contemporary EP than the prestige literary sixteenth century 'proclitic' grammar' (2011b: 83).

17 Only three examples of $e u$ - accusative clitic - não - verb have been found. What is more, they are interspersed inside the same texts with instances of clitic-verb adjacency (i. e. eu não o). Thus, these occurrences cannot be reliably associated with persistent individual grammatical habits of their authors. Yet, among other sequences with não picked out in the BND corpus, some do not have counterparts in instances of não-clitic-verb. For example, enganar-se 'be wrong' after the se subordinating conjunction occurs three times in association with the não-interpolation after the me pronoun in the BND corpus. The Cartas by Cavaleiro de Oliveira, a TBC text, contains, likewise, two occurrences of se me não engano 'if I'm not mistaken' and one of Se esses senhores se não enganam 'If these gentlemen are not mistaken.' No attestation of clitic-verb adjacency with this verb and the se conditional conjunction has been found. 
under Variation contexts 1, with enclisis reported to have become the prevalent pattern from approx. 1700 on. The text by de Figueiredo (born 1725), written way after this date, shows that clitic placement in such contexts fails to be definitely fixed. In some of the examples above (especially those where the interlocutor is not in the obligation to intervene), subject pronouns look as hanging topics, thus acquiring a clause-external status (Andrade 2018: 102). In other words, they are non-argumental (as French moi in Moi, je m'abstiens 'As for me, I'm abstaining').

This being said, it is worth reverting to the opinion of Martins (1994: 307) over the random distribution of the interpolation of não throughout the period under discussion.

\begin{abstract}
Esta variabilidade, que parece decorrer apenas de preferências individuais, mantém-se para além do século XVI. Na verdade, ao contrário do que poderia esperar-se, não se regista um progressivo decréscimo da ordem 'clítico-não-verbo,' a favor da ordem 'nãoclítico-verbo,' entre o século XVII e o XIX. Diferentes autores mostram diferentes tendências no que diz respeito à interpolação de não, sem que o factor cronológico se mostre relevante (1994: 307) 'This variation, which can be traced back merely to authors' individual choices, extends far beyond the $16^{\text {th }}$ century. As a matter of fact, between the $17^{\text {th }}$ and the $19^{\text {th }}$ centuries, the 'clitic-não-verb' order does not meet expectations and fails to become gradually superseded by the 'não-clitic-verb' order. Different authors exhibit divergent tendencies with respect to the interpolation of não, thus showing the irrelevance of the time criterion'
\end{abstract}

All in all, BND-based data do not lend support to 1700 as a starting point for the disappearance of interpolation outside obligatory proclisis contexts. Likewise, the criteria of the distribution of eu não o Verb and eu o não Verb are blurry and hard to grasp. Still, in the following section an attempt will be made to show that, rather than being a matter of purely stylistic factors, the distribution of the two syntactic patterns was not entirely random, with a series of phonological criteria making their interplay more transparent.

\title{
5 Interpolation and the loss of the affixal attachment of preverbal clitic pronouns
}

If all interpolation-inducing contexts are looked into, the average ratio of cliticverb non-adjacency to adjacency reaches 1.67: 1 (593 vs. 355 occurrences). Thus, não follows a clitic in $62.55 \%$ of all possible cases. Yet, in spite of the fact that the same set of morpho-syntactic features is encoded by each of the two linear patterns, they appear to have not been fully interchangeable. Over the period 
under discussion, they behaved differently with respect to the type of pronouns employed: third-person accusatives tended to be paired with interpolation, whereas the remaining pronouns evinced a more balanced distribution.

Table 8 shows that with the $o, a$, os, as series, the interpolation of não reaches $74.62 \%$ (150 out of 201 occurrences). By contrast, the distribution of the remaining pronouns does not depart significantly from the global average. Pearson's chi-squared tests (X-squared $=22.039, \mathrm{df}=7, \mathrm{p}=0.002501$ ) carried out on the figures from Table 8 show that the probability of the null hypothesis being correct is low ( $\mathrm{p}=0.002501)$. Thus, the difference between the variables under consideration ('non-adjacency' and 'adjacency') is statistically significant, thereby validating the observed distributions of real-text language data (Barbosa et al. 2017: 6).

Table 8: Number of occurrences and ratios of interpolation to clitic-verb adjacency of various classes of EP clitic pronouns (obligatory proclisis contexts and proclisis/enclisis variation contexts combined; BND data: 1614-1858).

\begin{tabular}{lrrrr}
\hline Type of pronoun & Occurrences & cl-V non-adjacency & cl-V adjacency & ratio \\
\hline se & 479 & $273(56.99 \%)$ & $206(43 \%)$ & $1.32: 1$ \\
o, a, os, as & 201 & $150(74.62 \%)$ & $51(25.37 \%)$ & $2.94: 1$ \\
lhe, lhes & 90 & $61(67.77 \%)$ & $29(32.22 \%)$ & $2.1: 1$ \\
me & 78 & $46(58.97 \%)$ & $32(41.02 \%)$ & $1.43: 1$ \\
nos & 41 & $28(68.29 \%)$ & $13(31.7 \%)$ & $2.15: 1$ \\
clusters & 26 & $17(65.38 \%)$ & $9(34.61 \%)$ & $1.88: 1$ \\
vos & 21 & $12(57.14 \%)$ & $9(42.85 \%)$ & $1.33: 1$ \\
te & 12 & $6(50 \%)$ & $6(50 \%)$ & $1: 1$ \\
Total of interpolation- & 948 & $593(62.55 \%)$ & $355(37.44 \%)$ & $1.67: 1$ \\
$\quad$ inducing contexts & & & & \\
\hline
\end{tabular}

After the subtraction of direct object pronouns, the figures for other clitic pronouns amount to 443 occurrences of non-adjacency versus 304 occurrences of adjacency, i. e. $59.3 \%$ to $40.69 \%$. At first glance, the gap between $74.62 \%$ and $59.3 \%$ is not dramatic. Yet, if transposed to ratios, it gives the following results: 2.94: 1 in favour of interpolation for the $o, a$, os, as series, and 1.45: 1 for the remaining pronouns. The question that calls for an answer at this stage is: why were 3rd person accusative clitics overrepresented in clauses with the interpolation of não?

In what follows, interpolation is being discussed mainly in connection with 3rd person accusative pronouns. The first step to gain insight into the mechanisms underlying their dominance in cl-não-Verb sequences is made once the 
syllabic structure of both não and 3rd person accusative pronouns is examined. The former ends in the branching nasal [ $\tilde{e} \tilde{w}]$ nucleus with no coda, whereas the pronouns consist only of a rhyme (Freitas 2016: 669-670). ${ }^{18}$ Encounters of verbfinal nasal diphthongs with 3rd person direct objects are known to trigger allomorphic variation in present-day standard EP. In the postverbal position, the [n] onset is obligatorily adjoined to the pronoun. Even if the same sound material happens to occur in expressions other than clitic accusatives (e.g. definite articles), allomorphy fails to appear.

(19) a. Viram-nas ( Viram-as)

see.PRF.IND.3.PL ACC.3.F.PL

'(They) saw them'

b. Viram as quebras (*Viram-nas quebras)

see.PRF.IND.3.PL ART.DEF.F.PL cracks

'(They) saw cracks (in it)'

c. Viu-as ( ${ }^{\star}$ Viu-nas)

see.PRF.IND.3.SG ACC.3.F.PL

'(He) saw them'

\subsection{The nature of affixal attachment}

Before embarking upon evolutionary issues, the concept of affixal attachment needs to be clarified first. It has always been a tricky issue in Romance linguistics to find out how clitics are processed and at which stage of speech

18 The phonological representation of nasal diphthongs, which play a central role in the sequences analyzed in this paper, is subject to lively debates. Controversies are due to the currently prevailing opinion that nasal vowels derive from tautosyllabic VN sequences ( $\mathrm{N}$ stands here for a nasal consonant non-specified for voice and place of articulation when occurring in the syllable coda). This hypothesis entails, following Câmara Jr. (1971: 33), that a nasal diphthong consists in an oral diphthong followed by a latent nasal archiphoneme. Under this interpretation, phonologically simple nasal vowels constitute closed syllables (Bisol and Veloso 2016: 69; Vigário 2003: 74). The argument usually advanced to substantiate this claim is related to stress assignment patterns in EP. In this language, diphthongs and closed syllables are bimoraic, hence heavy. By contrast, open syllables are light. Diphthongs, closed syllables and nasal vowels behave all alike with respect to stress placement. Lexical stress on the antepenultimate is only eligible in words with a penultimate light syllable. Words with nasal vowels and closed syllables in the penultimate are never proparoxytonic. Thus, syllable weight enables speakers to produce: estômago 'stomach' [(i) `tomegu], but prevents them from producing *estômangu or estômalgo. As nothing in this paper hinges on which position is chosen, we opt for a simpler solution (thus following Mateus and d'Andrade 2000). 
production they are inserted. The term coined by Zwicky (1977: 5), supposed to circumscribe their distribution, is 'special syntax.' Special clitics are, then, forms with stressed counterparts. Still, their syntactic properties deviate from those of the corresponding full DPs (see 20a-b).
(20)
a. Não conheço este livro
NEG know.PRS.IND.1.SG DEM book
'I don't know this book'
b. Não o conheço
NEG ACC.M.3.SG know.PRS.IND.1.SG
'I don't know it.'

The remaining arguments dealing with wordhood and affixhood of EP clitics are essentially built on the criteria worked out by Zwicky and Pullum (1983: 503-504) to pinpoint the differences between the English not and n't. Three of these criteria are particularly helpful for the discussion over EP clitic pronouns: (i) unlike clitics, which are moderately selective about the syntactic category of their host, affixes are highly selective with respect to the stems to which they are attached; (ii) morphophonological features of affixed words are more irregular than those of clitic-host groups; (iii) likewise, unpredictable restrictions on feature co-occurrence are found more often in affix-base combinations than in clitic-host groups. Additionally, clitics, but not affixes, can be added to material already containing clitics.

The first criterion shows that 'special clitics' do not occur in coordination (see 21a; cf. Luís 2014: 206), must be verb-adjacent (21b), and are never freestanding constituents bearing stress (for example, as contrastive foci; 21c). In (21d), where the verb is omitted, a 'strong pronoun' is mandatory, thus producing the clitic-doubling construction.
(21) $\quad$ a. ${ }^{\star} O$
João convidou-
0
e $a$
ART.M.SG John invite.PRF.IND.3.SG=ACC.3.M.SG and ACC.3.F.SG
(intended meaning) 'John invited him and her'
b. Quem é que tu viste? $-{ }^{\star} O$
who $Q$ you.NOM.SG see.PRF.IND.2.sG
(intended meaning) 'Whom did you see? - Him.'
c. ${ }^{*} \mathrm{Vi}$ - $\quad 0, \quad$ mas não $A$
see.PRF.IND.1.SG ACC.3.M.SG but NEG ACC.3.F.SG=FOC
(intended meaning) 'I did see him, but not HER'


d. $\mathrm{Vi}$ o, mas

see.PRF.IND.1.SG ACC.3.M.SG but

A ELA não $a \quad$ vi

to she.NOM.SG=FOC NEG ACC.3.F.SG see.PRF.IND.1.SG

'I saw him, but I didn't see HER'

The second criterion, almost always discussed in disregard of the properties of preverbal clitics, ${ }^{19}$ highlights the special phonology of clitic-verb sequences. Since phonological idiosyncrasy cannot be the result of productive phonological rules, scholars generally agree that its locus must be in the lexicon (Maiden 1995: 119-120). Therefore, it corroborates the claim that clitic pronouns are affixally rather than post-lexically attached. Two examples illustrate this point. Third person accusative pronouns surface as $l o, l a$, los, las if placed after verb forms ending in consonants: $s, z$, and $r$. Moreover, the $l$-variant deletes the final consonant of the verb form. Even if linguistic signs belonging to other categories display the same sound material, allomorphy fails to occur. ${ }^{20}$
a. Deves
pô-la
no
forno
must.PRS.IND.2.SG put.INF=ACC.3.F.SG in=ART.DEF.M.SG oven
'You should put it in the oven'
b. *Deves pôr a no forno
c. Deves
pôr
caçarola no
must.PRS.IND.2.SG put.INF ART.DEF.F.SG casserole in=ART.DEF.M.SG
forno
oven
'You should put the casserole in the oven'
c. `Deves pô-la caçarola no forno

\footnotetext{
19 In present-day standard EP, no clitic-specific phonological change occurs in the preverbal position. The only frequent change is optional and independent of the category membership of the juxtaposed segments. It involves glide insertion in sequences consisting of a [ə] schwa and an ensuing vowel. The process takes place both word-internally and across word boundaries. As for clitic-verb sequences, [j] is optionally inserted (e. g. te odeiam '(they) hate you' surfacing either as [to] or as [tj]]). Likewise, liaison occurs after function words (prepositions and conjunctions) followed by 3rd person accusative pronouns (se a vires 'if (you) see her,' surfacing either as [se] or as [sje]; see Vigário (2003: 106-108). The optionality of this hiatus-breaking operation is thought to lend support to the post-lexical phonology of preverbal clitics (Luís and Kaiser 2016: 220).

20 One notable exception to this morphophonological process is also clitic-specific: $l$-insertion and final consonant deletion take place within clitic groups juxtaposing indirect and direct objects: no-lo 'it to us' and vo-lo 'it to you.PL,' which filter out, respectively, *nos-o and *vos-o.
} 
Another illustration of the second criterion has to do with the nos enclitic, which deletes the final [s] of 1.PL verb forms (see 23). No comparable phenomena are observed elsewhere, even if non-clitic expressions consist of the same phonological segments: Estamos nos correios '(We) are at the post office'/ ^Estamo nos correios. If nos follows any other consonant-final verb form (even ending in -s), allomorphy does not appear.
a. alegramo-nos 'we are pleased,' *alegramos-nos
b. alegrámo-nos 'we were pleased,' *alegrámos-nos

Arbitrary gaps refer to 'out-of-the-blue' restrictions on feature co-occurrence (Miller and Monachesi 2003: 87-88). An illustrative gap involves the underspecification of the 3rd person dative for the features [singular] and [plural]. If used as the only clitic, its number is consistently marked in present-day EP. If used in clitic clusters, it becomes deficient in number marking. The clusters lho, lha, lhos, lhas fail to express how many individuals are actually concerned. For example, Transmitiram-lho could mean either '(they) transmitted it to him/her' or '(they) transmitted it to them., 21

Additionally, in individual inflected forms, the l-insertion and final consonant deletion are blocked. For example, quer '(he / she) wants' does not turn into *quê-lo, as expected under this rule. Instead, it surfaces as quere-o.

21 However, if some of their properties are carefully analyzed, the assumption that clitics combine with stems in much the same way as affixes do does not go unchallenged. In fact, substantial counterevidence highlights the properties that clitics share with fully-fledged words, thereby posing a serious problem to their treatment in terms of affixhood (Vigário 2003: 131155). Essential criticism lies in the ability of clitic pronouns to occupy variable positions with respect to the verb, something that affixes normally do not do. Likewise, if stress-assignment in verb-clitic combinations is considered, object clitics are inserted in defiance of the 'threesyllable window' (Luís and Kaiser 2016: 214). EP word stress is known to travel, at most, as far as to the third syllable from the right. This rule holds true for the inflected forms in verbal morphology as well (entregávamos 'we were handing over' 1.PL.IPFV.IND). This locus is maintained throughout, irrespective of whether enclitics attach or not to the forms with lexical stress on the antepenultimate. If enclitics had really been the product of affixal attachment, the word stress would have been coerced into moving onward. Yet, this change fails to materialize: entregávamo-vo-los '(we) were handing it over to you.PL,' ‘entregavamó-vo-los. 


\subsection{Increasing restrictions on affixal attachment of preverbal clitics}

In her analysis of clitic placement in subordinate clauses, Namiuti (2008: 104-105) emphasizes the importance of the direct sequencing of complementizers and pronouns in Old Portuguese. In her opinion, such configurations, which originate from clitic movement to $\mathrm{C}$, prompted all kinds of interpolations found in Medieval texts: rather than preceding the pronoun, any other expressions (X) tended to be inserted between a clitic pronoun and the verb so that the contiguity of proclisis triggers and clitic pronouns would be upheld throughout. Once clitics had been prevented from moving higher than to $\Sigma$, the $\mathrm{C}$-cl-(X)-negV order began receding in favor of the complementizer-clitic non-adjacency: (C)-X-clnegV. Yet, the disappearance of the former order has never become complete. ${ }^{22}$

Now, it must be elucidated how the complementizer - clitic contiguity unveils the dominance of accusative pronouns in clauses with the interpolation of não in Classical Portuguese. One of the effects it had in Old Portuguese consisted in frequent liaisons between object pronouns and the expressions that surrounded them. The essential feature of this process has been insightfully captured by Sandalo and Galves (2013: 126) in terms of Merger (theory-internally defined concept taken over from Distributed Morphology). Mergers operate on separate units and establish strong morphophonological links between them. Unlike after undergoing prosodic attachment, clitics, if they merge with their hosts (or stems), evolve into affixes. In Old Portuguese, fusions appeared both with the preceding and the ensuing sound material. As for the latter variant, the encounter of pronominal (not only 3rd person) vocalic nuclei with vowel-initial verb forms resulted in vowel deletions. One of the effects such fusions had was to obviate the emergence of heterosyllabic vowel clusters. Such cases are comprehensively discussed by Martins (1994: 217-218), e.g. sobligarõ (< se obrigaram '(they) took an obligation onto themselves'), todo lhera prazer ( $<$ tudo lhe era prazer 'everything was a pleasure for him'), etc.

Things were far more complicated if clitic pronouns merged with the preceding non-verbal sound material. A significant number of expressions hosting clitics in such linear configurations had, at the same time, the property of

22 The mere fact that the interpolation of não is possible in Classical and in Contemporary EP means that it is not dependent on clitic movement to $\Sigma$, but behaves as an affix-like element projected in association with the verb. According to Martins (1994), this happens because Neg is not an autonomous syntactic nucleus in the languages that admit não interpolation. On the contrary, it lexicalizes $\Sigma$ (nucleus of $\Sigma \mathrm{P}$ ), in the grammars that do not admit this syntactic pattern. 
coercing them into being preverbal: (i) complementizers and interrogativerelative pronouns, (ii) quantifiers and preverbal placement-inducing adverbs, (iii) negative words. Occasionally, clitics were subject to fusions also with (iv) strong subject pronouns (favoring, albeit not coercing, the preverbal placement) that preceded them. Unlike in liaisons occurring with an ensuing verb form, 3rd person direct object pronouns were the only type of clitics capable of undergoing mergers. In such configurations, they were, then, affixally attached to (nonverbal) proclisis triggers. Example (24) below illustrates morpho-phonological ties bringing together 3rd person accusative pronoun and the preposition por on its left. The reanalysis (the coda of the por preposition evolves into 1, syllabified as the onset of the subsequent pronoun) of the initial por o sequence as polo clearly indicates that hiatus-breaking was not the only function of proclisis trigger - clitic pronoun fusions.

$$
\begin{array}{llll}
\text {... todos pediaõ } & \text { o } & \text { mofteiro, polo } \\
\text { all.M.PL ask.IPFV.IND.3.PL } & \text { ART.DEF.M.SG } & \text { Monastery for=ACC.3.M.SG } \\
\text { naõ auer neftas } & \text { partes, ... }(\text { polo }<\text { por } o)^{23}
\end{array}
$$

NEG be.INF in=DEM.F.PL side.PL

'(a petition signed by two hundred citizens, in which) all of them asked for a monastery, because there was none nearby' (1640. Anonymous. Relaçam verdadeira do milagroso portento; p. 6) purl.pt/16740

In the preverbal position, não is the best documented allomorphy trigger even in Classical Portuguese. Its persistance is traced back to the $\mathrm{C}$-cl combinations referred to in the preceding paragraph. As the negative marker ends in the [ẽ w] nasal diphthong, it was likely to induce the $o, a$, os, as pronouns into acquiring the $[\mathrm{n}]$ onset. Therefore, it optionally produced the same effect as the one that pervades today's verb - 3rd person accusative sequences (assuming a

23 Interestingly, the juxtaposition of por, the accusative clitic pronoun and the não negative always follows this particular ordering in the BND corpus. Moreover, the sequence is always subject to an allomorphic change (surfacing either as pelo or as polo; e. g. ..., os granadeyros da cortadura, pelos não ter vifto como os mais fem ordem dos feus officiaes, ... '... the grenadiers wearing edged weapons, for they were unable to see them, like the remaining ones, without having been given orders by their commanding officers ...;' 1714. Anonymous. Relaçam da campanha de Alem-Tejo ...; p. 45). This is to say that por não - third-person direct object clitic sequences are missing in the BND. At the same time, the remaining pronouns sometimes do follow the por não sequence, including as enclitics after non-finite forms ( ..., fó por não dar-lhe hum incommodo tal 'so as to spare her this kind of discomfort;' 1804-1810. Manuel de Figueiredo. Escola da Mocidade I,2; p. 12). 
nasal diphthong in the verb's final segment; as in (19a) above). This is an instance of clitic-specific allomorphy in preverbal position. Finally, [n]-insertion is peripherally found after the quem ('who') relative-interrogative pronoun, the ninguém 'nobody' indefinite, and nem, the second element of coordinate correlative negative sequences (não ... nem, nem ... nem 'neither ... nor;' Sánchez López 2017: 649). All of them are similar to não in that they end in the nasal falling diphthong.

$\begin{array}{llccc}\text { a. ... naõ no } & \text { fazendo } & \text { defde o } & \text { dia } & \text { que } \\ \text { NEG } & \text { ACC.3.M.SG do.PRS.PTCP } & \text { since } & \text { ART.DEF.M.SG day } & \text { REL } \\ \text { lhe } & \text { puzerem } & a & \text { dita } & \text { pena ... } \\ \text { DAT.3.SG } & \text { put.FUT.SBJV.3.PL } & \text { ART.DEF.F.SG } & \text { say.PST.PTCP.F.SG } & \text { punisment }\end{array}$
'... not doing this from the day when he will receive this punishment' (1639. Regimento dos Juizes das Aldeas, ...; p. 6) purl.pt/14985

b. ... [e] aquella nona mostre and DEM.DIST.F.SG NEG=ACC.3.F.SG display.PRS.SBJV.3.SG

nẽna tena en logar $u$

nor=ACC.3.F.SG have.PRS.SBJV.3.SG in place where.REL ACC.3.F.SG

ueya nenhũa das partes

see.PRS.SBJV.3.SG any.F.SG of=ART.DEF.F.SG side.PL

'(If by chance it is lost or any suspicion or doubt arises over it, it must be proved by a note where it was lost) and it must not be either publicly exposed or stored in a place where any of the sides can have a look at it' $\left(13^{\text {th }}\right.$ century. Foro Real. Liv. 1, Cap. 8, Fól. 79v) cipm.fcsh.unl.pt/

c. ... ca teuerõ que he melhor cousa be.cause have.PRF.IND.3.PL COMP be.PRS.IND.3.SG best thing e mays sem perijgo de casar ca de prometer and more without danger of get.married.INF than of promise.INF castidade e nõna poder mãteer chastity and NEG=ACC.3.F.SG can.INF maintain.INF '... they thought that it was better and safer to get married than to promise chastity and be unable to keep it' (Afonso X. Primeira Partida. Tít. 9, Lei 39, Fól. 93c; $14^{\text {th }}$ c.)

Phonological conditioning of this clitic-specific allomorphy is going to be formalized in terms of the serial model of syllabification, inspired by X-bar Theory (Colina 2012: 133; Hualde 1991), adopted for EP. Under this proposal, a nucleus projects three constituents: $\mathrm{N}, \mathrm{N}^{\prime}$ and $\mathrm{N}^{\prime \prime}$. The $\mathrm{N}^{\prime \prime}$ node corresponds to the syllable level. Onset segments are attached directly to $\mathrm{N}^{\prime \prime}$ whereas nucleus and coda are attached to $\mathrm{N}$ and $\mathrm{N}^{\prime}$ respectively. $\mathrm{N}^{\prime}$ represents the rhyme. 
Competing realizations of preverbal 3rd person accusative pronouns following the não negative marker hinge on how many times Rule 3 below is applied. The two variants might be depicted as two different outcomes achieved by means of the sequential application of the Rule 1, Rule 2 and Rule 3 (Figures 1-3).

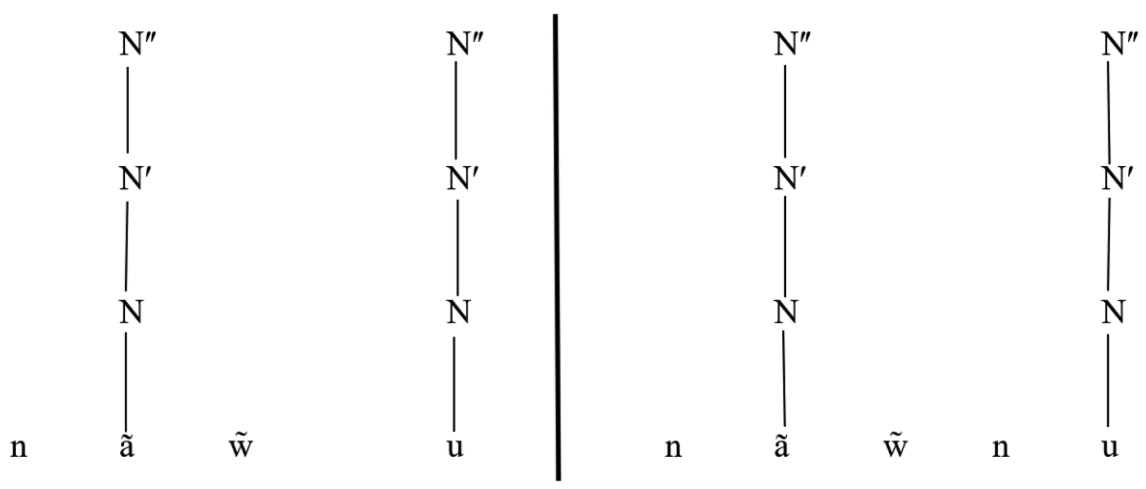

Figure 1: (Rule 1): Identify Nucleus: [- consonantal] segments project a syllable ( $\left.N, \mathrm{~N}^{\prime} \mathrm{N}^{\prime \prime}\right)$.
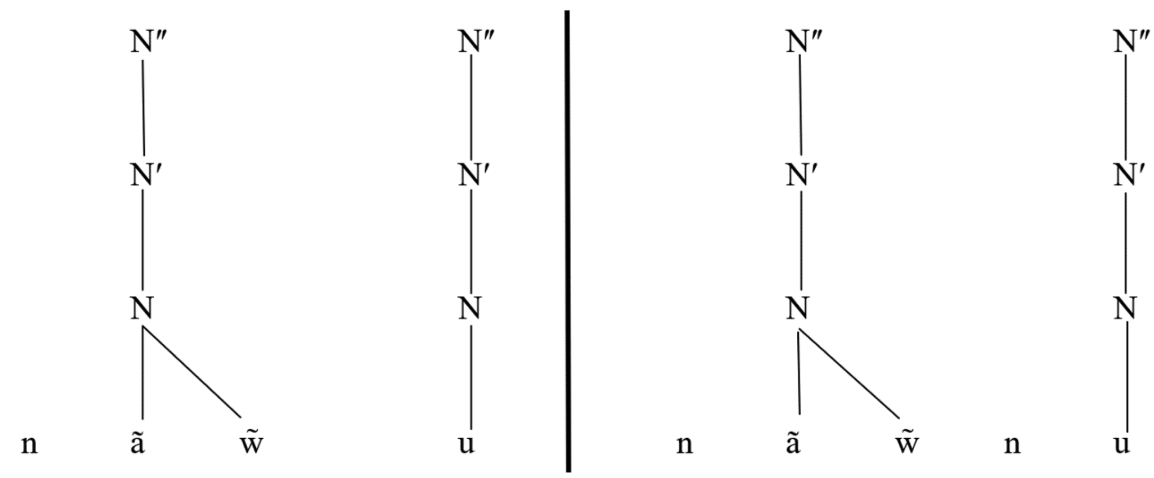

Figure 2: Rule 2 (Complex Nucleus): attach a postvocalic nasal glide, i. e. to the right of the nucleus under the $\mathrm{N}$ node, thereby producing a falling diphthong (Freitas 2016: 669-670).

An important feature of sequences generated by the double application of the Onset Rule consists in the sameness of realization of third person accusative clitics in both preverbal and postverbal position if only sound characteristics of the preceding linguistic material are the same. Indeed, complex nasal nuclei are shared by the last syllable of both the negative marker (as well as by ninguém, 

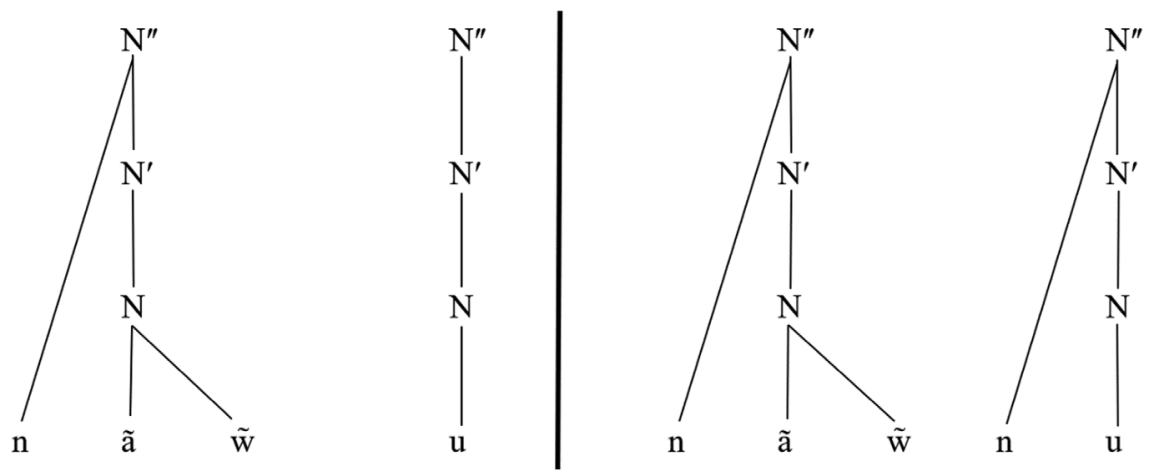

Figure 3: Rule 3 (Onset Rule): attach a nasal consonant to the left of the nucleus under the $\mathrm{N}^{\prime \prime}$ node (applicable once for não o, twice for não no).

quem, and nem) preceding a clitic and the verb form hosting n-initial enclitic accusative pronouns. Judging by the presence of sequences such as não $=n o$, quem $=$ no, ninguém $=$ no, etc. in Old and Classical Portuguese texts, the sameness of sound characteristics is assumed to have been an important signal for the speakers on how clitics should be processed and how they should surface.

Obviously, not after all of the occurrences of não, nem, ninguém and quem did preverbal 3rd person direct object clitics undergo the syllabic change in question even in the past stages of EP. It looks as if the decision as to whether or not the merger between the pronouns and the preceding units should be applied were speakers' individual choice.

$$
\begin{aligned}
& \text { a. ... o furor do povo } \\
& \text { ART fury of=ART.DEF.M.SG people }
\end{aligned}
$$

ninguem o podia conter.

'... the fury of the people, nobody was able to restrain it' (1809. Carta que escreve hum militar portuguez de Saragoça aos seus amados compatriotas ...; p. 11) purl.pt/14932
b. ..., foccorria
às
necefsidades
guarantee.IPRF.IND.3.SG to=ART.DEF.F.PL need.PL

\section{de quem o auifauão.}

of who ACC.3.M.SG warn.IPFV.IND.3.PL

'... he fulfilled the needs of those who would warn him' (1614. Nicolao Agostinho. Relaçam summaria da vida do ... Senhor Dom Theotonio de Bragãça. Cap. XIII; pág. 113) purl.pt/11490 
Now, reverting to [n]-insertion contexts, branching nasal nucleus preceding empty onset pronouns is a necessary, yet insufficient condition. Indeed, not all proclisis triggers produced this allomorphic change, even if they exhibited suitable syllabic structure. Sub-categorization restrictions appear to have come into play as well. For example, written records offer no attestation of preverbal pronoun allomorphy after the adverb bem [bẽj] 'well.' In other words, a sequence such as bem no sei 'I am well aware of it' is absent throughout, regardless of the fact that bem coerces pronouns into being preverbal (see 27a-b) as well.

$$
\begin{aligned}
& \text { a. ..., por mais cuidados que delle teue } \\
& \text { by so much care.PL COMP of=him. have.PRF.IND.3.SG }
\end{aligned}
$$

In a nutshell, rather than being dictated on a regular basis by phonology, [n]-insertion must have been brought about with the aid of an intricate network of rules from various levels of speakers' individual grammars. Therefore, explanations relying exclusively on a single level of analysis, be they purely syntactic (clitic and verb movement, IP-scrambling) or semantic, ${ }^{24}$ are intrinsically unable to capture all of the facets of the interplay between clitic-Verb adjacency and non-adjacency in Classical Portuguese. An interface approach is needed in their stead.

24 Semantically based explanations of the dominance of the não negative marker in clauses with interpolation rely on the observation that negation carries a heavy communicative load (Dryer 1988: 99, 102). Therefore, it constitutes an essential part of the message: if a hearer fails to recognize the negation in the flow of an utterance, the intended meaning of a sentence is fundamentally misinterpreted. Unlike in propositional calculus where negation has scope over the entire clause, natural language subjects remain generally immune to sentential negation (Zanuttini 2001: 511). Instead, the proper domain of the latter involves the verb-object combination. Moreover, typological research demonstrates that semantically interrelated units (such as negation and the verb) tend to surface next to each other in sentences. 


\section{Discussion: Competing motivations in phonological change and present-day outcomes}

For want of clear-cut criteria stating what form preverbal accusative clitics should take, speakers might have been led to fall back on an intuitively perceived analogy, drawing a parallel with the forms taken by enclitics in the same phonological environments. Obviously, this method brought very unsteady results. Moreover, the cues provided by the syllabic structure for the treatment of accusative pronouns ran athwart the ban on clitic-specific allomorphy in the preverbal position. By contrast, both [n]-onset insertion and standard $o, a$, os, as forms were compliant with the 'clitic by the verb' requirement.

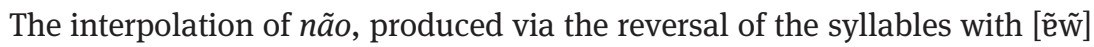
and $[\mathrm{u}]$ nuclei, helped do away with speakers' doubts over the attachment of preverbal clitic pronouns, thus prompting their more consistent treatment. Furthermore, the semantic properties of não were considered favorable to its appearing verb-adjacently (see footnote 25). Still, interpolation was costly in that it was practised in defiance of the 'clitic by the verb' parameter, the increasing significance of which at the onset of Modern Portuguese was due to the loss of clitic movement to the higher functional domain. Once affixal attachment in the preverbal domain had been weakened, the way became open to the emergence of the modern clitic system. The syllabic structure of all of the remaining pronouns and clitic clusters, none of which has an empty onset, was less troublesome. Therefore, they did not run the risk of being subject to allomorphy. Accordingly, their preverbal and postverbal forms were (and still are) all alike. No wonder that, compared to 3rd person accusative pronouns, they occurred separated from the verb with a lesser frequency.

All these factors provide a plausible explanation of the overrepresentation of $o, a$, os, as in clitic-não-verb sequences in Classical and early Modern EP. This view subscribes to some of the tenets of usage-based theories of grammatical change (Bybee 2011: 69-70), which emphasize the importance of repetitive uses of certain variants in producing a new pattern. If some critical number of their occurrences in language communication is exceeded, a durable change ("observable manifestation of grammar innovations in speech," Andersen 2001: 225) is eventually produced. Developments along these lines do not entail acting on purpose. The loss of the [n] insertion appears, instead, to be no more than a side-effect of the preference for cl-não-verb sequences in the period under discussion. 
In today's theoretical linguistics, the scenario outlined above is associated with the concept of 'competing motivations' (Moravcisk 2010, Moravcisk 2014). They are posited for explanatory purposes and are expected to provide answers to the why-questions in linguistic typology, regardless of theoretical choices. Explanations are couched in terms of mutually exclusive desiderata inherent in human speech processing, such as the speaker's needs as opposed to the listener's demands, recurrent means of encoding a given meaning versus the economy. Each reasoning along these lines relies on two claims: there are at least two motivations at work (M1 and M2) and M1 and M2 are in conflict. In more formal terms: Apart from M1, which predicts the structure A and excludes the structure B, there is also M2, which predicts B and excludes A (Furtado da Cunha 2001: 15-17).

The mechanics of clitic placement (adjacency vs. non-adjacency) and clitic realization (with vs. without allomorphy) in Classical and early Modern Portuguese are assumed to be best approached in terms of a series of typological clashes. In the first step, the following two motivations came into conflict: M1 homogeneous realization of accusative clitics in both preverbal and postverbal position in the same phonological conditions (corresponding structure: que não no viu); M2 - ban on the fusion of proclisis triggers and preverbal clitic pronouns (corresponding structures: que o não viu and que não o viu). Variation was due to the fact that these constraints were unlikely to be satisfactorily fulfilled all at once. In pursuance of their communicative goals, speakers would privilege one of the two motivations. The other they played down or ignored altogether.

At the onset of Classical Portuguese, the following solution was opted for: M2, which rules out affixal attachment in the preverbal domain, did away with M1, leaving the structures que o não viu and que não o viu as the only viable outcomes. This scenario is called override ('winner takes all,' Moravcsik 2014: 3-4, 6) and accounts for the disappearance of que não no viu. ${ }^{25}$ In the first phase, allomorphyavoidance (M2) proved, then, more compelling than the need for the sameness of processing of preverbal and postverbal 3rd person accusative clitics in the same phonological environment. Thus, M2 eventually trumped M1. This step is likely to

25 Three other scenarios envisaged in Moravcsik's calculus are: separation, compromise and deadlock. Their definitions all have in common the formula: 'In addition to M1, which predicts A and excludes B, there is also M2, which predicts B and excludes A.' The first scenario takes place if the domain of M1 and M2 splits: each yields its own structure A and B, with each motivation overriding the other in a separate domain. The conflict is settled by compromise if the content of both motivations M1 and M2 is adjusted within a single resulting structure that is similar to but not the same as A or B. Finally, for want of a constructive solution, a stalemate may eventually come about: neither A nor B fits. A completely new structure, unrelated to M1 or to M2, must be devised to replace the internally conflicted one(s). 
be described also as an instance of paradigm leveling (Fertig 2016: 427-428): all preverbal pronouns began to take a single form irrespective of phonological characteristics of their syntagmatic partners. Once preverbal clitic allomorphy was definitely banned from the standard scriptural production, the conflict spread over the motivations underlying the two remaining structures. In early Modern Portuguese, possible violations of the 'clitic by the verb' principle were overridden (or seriously undermined) by the adjacency requirement. The latter change, although formulated on the basis of different premises, captures the same evolutionary effect as Namiuti's finding that, at the onset of Modern Portuguese, verbs became confined into I.

Finally, it remains to be seen what are the nineteenth and the twentiethcentury outcomes of the affixal attachment discussed above. The evidence comes from the analysis conducted in the CdP - corpusdoportugues.org, in its currently available version (so called 'CdP:New,' approx. 1 billion words of data). Only the 1800 s and the 1900s are represented in the 'Genre/Historical' sub-corpus, which coincides with the Modern Portuguese era. As for [n]-insertion in preverbal direct object pronouns, the 'Web/Dialect' and the 'NOW (2012-this past month)' subcorpora do not bring any results whatsoever.

The search involved three lexemes - quem, ninguém and não. In the first step, the query focused on preverbal allomorphic realizations. Out of twelve conceivable combinations (quem no, quem na, quem nos, quem nas; ninguém no, ninguém na, ninguém nos, ninguém nas and não no, não na, não nos, não nas), only nine have been retrieved. Quem nos, ninguém nos and não nos have been left out of analysis because of an all-encompassing homonymy with nos 1st person plural pronoun. Sorting through the intended values of nos in such contexts is a feasible task. Yet, its completion has been judged disproportionately costly, as seen against its relevance for an aggregate result.

The search conducted in the 'Genre/Historical' sub-corpus has brought 34 hits (quem no - 6, quem na - 3, quem nas - 5, ninguém no - 3, ninguém na - 3, não no - 5, não na - 5, não nas - 4). No examples of ninguém nas have been found. All of the hits have been drawn from the 'Fict' section, earmarked for literary production. By contrast, no hits have been found in the remaining three sections ('oral,' 'acad' and 'news' containing twentieth and twenty-first-century data only). These figures reveal the sociolinguistic and diamesic (i. e. depending on the medium of communication) profile of the preverbal allomorphic variants in Modern EP. An interesting feature is the monopoly of literary examples (most of them from the twentieth century). Moreover, the analysis of discourse contexts shows that n-initial forms tend to appear in dialogue scenes, or in scenes that try otherwise to imitate the spoken register. This characteristic is somewhat surprising in light of the fact that allomorphic variants are in no way represented 
in the 'oral' section of the 'Genre/Historical' sub-corpus. Authors' heavy-handed attempts at reconstructing the flow of 'real-life' conversations provide a plausible explanation.

... não tem experiência nenhuma da

NEG have.PRS.IND.3.SG experience none.F.SG of=ART.DEF.F.SG

life keep.PRS.IND.3.SG ART.DEF.F.SG tenderness intact.F.SG

vida. Conserva a ternura intacta.

Ninguém na ouve.

nobody ACC.3.F.SG hear.PRS.IND.3.SG

'(she) hasn't any life experience. She has her tenderness intact. Nobody can hear her’ 1917. Raúl Brandão, Húmus. www.corpusdoportugues.org/ hist-gen/

In the second stage, bare $o, a$, os, as realizations directly following quem, ninguém and não have been looked for. Unlike allomorphic sequences, they are found in all the sections of the CdP:New, thereby covering all registers, degrees of formality, means of communication and discourse contexts. Likewise, they are not restricted to the 'Genre/Historical' sub-corpus but are also found in the 'Web/ Dialects' and the 'NOW (2012-this past month).' They outnumber by far allomorphic variants referred to above. For example, the search for the não a sequence (excluding definite articles and demonstrative pronouns) only in the twentieth century section of the 'Genre/Historical' sub-corpus has brought 482 hits.

To ascertain whether onset insertion to preverbal accusative clitic pronouns is still extant in non-standard EP, a search was also run in the CORDIAL-SIN (Syntaxoriented Corpus of Portuguese Dialects; Martins (coord.) 2000-), an interview-based collection of spoken dialectal data. It consists of samples of geographically diffuse (42 localities in both inland and insular Portugal), spontaneous and semi-directed speech. The 'verbatim transcription' section contains, alongside standard expressions, the annotation of pauses, hesitations, phonetic and morphological distortions, reiterations, truncated words, and all kinds of devious productions. Fortyfive occurrences of $n$-initial preverbal accusative clitic pronouns have been revealed in fifteen interviews. In all of them, non-standard and standard variants occur intermixed in the same syntactic configurations. In the same interviews, seventy vowel-initial preverbal accusative clitics, in contextually equivalent conditions, have been retrieved. In the remaining 27 localities, no onset insertion has been found in preverbal accusative clitics. The search included eight proclisis triggers, all of them ending in a nasal diphthong: não, quem, ninguém, sem, em, também, alguém and nem. Table 9 cross-checks the two realizations against seven 
Table 9: The distribution of the sequences 'proclisis trigger - preverbal accusative clitic' in the 15 interviews with divergent realizations. Source: CORDIAL-SIN.

\begin{tabular}{lrrr}
\hline sequences with $n$-insertion & 45 & vowel initial sequences & $\mathbf{7 0}$ \\
\hline quem no (na, nos, nas) & 10 & quem o $(a$, os, as $)$ & 2 \\
não no (na, nos, nas) & 27 & não o $(a$, os, as $)$ & 54 \\
ninguém no (na, nos, nas) & 2 & ninguém o $(a$, os, as) & 3 \\
nem no (na, nos, nas) & 3 & nem o $(a$, os, as) & 1 \\
também no (na, nos, nas) & - & também o $(a$, os, as) & 10 \\
sem no (na, nos, nas) & 2 & sem o $(a$, os, as) & - \\
em no (na, nos, nas) & 1 & em o $(a$, os, as) & - \\
\hline
\end{tabular}

proclisis triggers (neither alguém o/a/os/as nor alguém no/na/nos/nas are present in the corpus) in the fifteen localities where variation was found.

Be that as it may, consonant-initial preverbal accusative clitics are still extant in non-standard EP. Even if CORDIAL-SIN data are insufficient to be entirely probative, some local tendencies are conspicuous. The archipelago of the Azores and the North of the mainland Portugal stand out as the areas where variation is most prominent.

As in the localities selected for the survey usually more than one person was interviewed, it has also been checked whether the two competing realizations are found alongside in single interviewee's speech. This expectation is borne out in nine out of fifteen localities (Enxara do Bispo - Lisbon district, Ribeira Seca - Angra do Heroísmo district, Melides - Setúbal district, Granjal - Viseu district, S. Lourenço de Montaria - Viana do Castelo district, Fajãzinha and Ribeira do Meio - Horta district, Covo - Aveiro district and Perafita - Vila Real district). In six of them, standard and non-standard forms do not alternate in the speech of the same individuals (Vila do Corvo - Horta district, Castro Laboreiro - Viana do Castelo district, Santa Cruz da Graciosa and Fontinhas - Angra do Heroísmo district, Outeiro - Bragança district and Santo André - Vila Real district). ${ }^{26}$

26 What these results reveal is the sameness of the processing (not to be confused with the historical continuity) of clitic pronouns between present-day dialectal EP and medieval Portuguese. In the texts of both CIPM and CORDIAL-SIN corpora, preverbal accusative clitics have two limitedly interchangeable realizations. Their variation is constrained by phonological factors: whether the n-initial variant may appear or not hinges on the syllabic structure of the proclisis trigger - accusative clitic sequence. Both periods are alike also in that the onset insertion is not clitic-specific. Proof of this are mergers likely to affect verb form - definite article or preposition - definite article sequences if requirements regarding syllabic structure are met. In point of fact, CORDIAL-SIN's interviews contain multiple occurrences of onset insertion to definite articles following verb forms ending in a nasal diphthong. For example, 


\section{Concluding remarks}

In this paper, after an extensive empirical study on the BND texts, we elaborate on the position of the negative marker não in Classical and early Modern European Portuguese. It was the only expression likely to be interpolated between a clitic pronoun and the verb. Our analysis builds on the simple fact that amid a multitude of existing in-depth studies on Portuguese interpolation, none seems to have taken advantage of the distribution of particular classes of clitic pronouns. Obviously, quantification itself was not the goal pursued here. Instead, it helped determine the significance of the distribution of various types of clitics. Their uneven representation, namely the prominence of accusative clitics in two syntactic patterns: interpolation and clitic-verb adjacency, appears to have been an important step towards the ultimate loss of não interpolation in standard Modern EP.

Moreover, we propose that the explanation for the interpolation of não must have an interface nature: not only did morphosyntactic or semantic features (related to verb and clitic movement and the nature of Negation) play a role, but also phonological factors. Along these lines, interpolation is thought to have been an allomorphy-preventing strategy. This syntactic pattern helped to get rid of the affixal attachment of the $o, a$, os, as series to the preceding non-verbal expressions having an appropriate phonological structure. The phenomenon has also been shown to be tied to how enclitic configurations are realized in Contemporary EP.

Acknowledgements: We wish to thank the editors of this volume and two anonymous reviewers for their insightful and helpful comments given to an earlier version. The remaining drawbacks are ours. The research whose results are exposed in the present paper has been funded by National Science Centre (Narodowe Centrum Nauki) under the agreement UMO-2016/22/M/HS2/00168 (funding initiative Harmonia8). Although the paper is the result of a continuous exchange of ideas, Alexandra Fiéis has been responsible for writing Sections 2 and 4. Mikołaj Nkollo is responsible for Sections 3, 5 and 6.

['teẽnez] = têm as mesmas diferenças que nós temos cá 'they have the same differences as we have here' (Serpa, Beja district, male informant, 50 years, illiterate; tapescript from the 'verbatim transcription' section). Likewise, Old Portuguese texts stored in the CIPM offer a rich attestation of onset insertion to the definite article after certain prepositions (com, sem, em). Cf. ... ca o pesar e o arrepẽdimẽto e a (con)fissom sena enmẽda, nõ he nada, ... 'because contrition and penance and confession without amends are worthless' (Afonso X, Primeyra Partida, 6.21.46c). 


\section{References}

Andersen, Henning. 2001. Actualization and the (uni)directionality of change. In Henning Andersen (ed.), Actualization. Linguistic change in progress. Papers from a workshop held at the 14th International Conference on Historical Linguistics, Vancouver, B.C., 14 August 1999, 225-248. Amsterdam \& Philadelphia: John Benjamins. https://doi.org/10.1075/cilt.219.11and.

Andrade, Aroldo Leal de. 2018. A special type of left dislocation in Galician and Portuguese: The D-construction. Estudos de Lingüística Galega 1. 81-105. https://doi.org/10.15304/elg. ve1.3510.

Andrade, Aroldo Leal de \& Cristiane Namiuti-Temponi. 2016. Gone without the verb: Clitic interpolation and clitic climbing in the history of European Portuguese. Cadernos de Estudos Linguísticos 58(2). 201-216.

Barbosa, Pilar 1996. Clitic placement in European Portuguese and the position of subjects. In Aaron Halpern \& Arnold Zwicky (eds.), Approaching second: Second position clitics and related phenomena, 1-40. Stanford, California: CSLI Publications.

Barbosa, Pilar P., Maria da Conceição de Paiva \& Celeste Rodrigues. 2017. The study of variation in Portuguese. Overview and outlook. In Pilar P. Barbosa, Maria da Conceição de Paiva \& Celeste Rodrigues (eds.), Studies on variation in Portuguese, 2-20. Amsterdam \& Philadelphia: John Benjamins. https://doi.org/10.1075/ihll.14.int.

Battye, Adrian \& Ian Roberts. 1995. Introduction. In Adrian Battye \& lan G. Roberts (eds.), Clause structure and language change, 3-28. Oxford: Oxford University Press.

Bisol, Leda \& João Veloso. 2016. Phonological processes affecting vowels: Neutralization, harmony, and nasalization. In W. Leo Wetzels, Sergio Menuzzi \& João Costa (eds.), The handbook of Portuguese linguistics, 69-85. West Sussex: John Wiley \& Sons, Inc. https://doi.org/10.1002/9781118791844.ch5.

Blas-Arroyo, José Luis \& Kim Schulte. 2017. Competing modal periphrases in Spanish between the 16th and the 18th centuries. A diachronic variationist approach. Diachronica 34(1). 1-39. https://doi.org/10.1075/dia.34.1.01bla.

Bybee, Joan. 2011. Usage-based theory and grammaticalization. In Heiko Narrog \& Bernd Heine (eds.), The Oxford handbook of grammaticalization, 69-78. Oxford: Oxford University Press. https://doi.org/10.1093/oxfordhb/9780199586783.013.0006.

Câmara Jr, Joaquim Mattoso. 1971. Problemas de lingüística descritiva. Petrópolis, RJ: Editora Vozes Ltda.

Castro, Ivo. 2006. Introdução à história do português, 2nd edn. Lisboa: Edições Colibri.

Colina, Sonia. 2012. Syllable structure. In José Ignacio Hualde, Antxon Olarrea \& Erin O’Rourke (eds.), The handbook of Hispanic linguistics, 133-151. West Sussex UK: John Wiley \& Sons, Ltd. https://doi.org/10.1002/9781118228098.ch7.

Costa, João \& Ana Maria Martins. 2010. Middle scrambling with deictic locatives in European Portuguese. In Reineke Bok-Bennema, Brigitte Kampers-Manhe \& Bart Hollebrandse (eds.), Romance languages and linguistic theory 2008. Selected papers from 'Going Romance' Groningen 2008, 59-76. Amsterdam: John Benjamins. https://doi.org/10.1075/rllt.2.05cos.

Donaldson, Bryan. 2014. Socio-stylistic reflexes of syntactic change in Old French. Journal of French Language Studies 24(3). 319-345. https://doi.org/10.1017/S0959269513000203.

Dryer, Matthew S. 1988. Universals of negative position. In Michael Hammond, Edith A.

Moravcsik \& Jessica Wirth (eds.), Studies in syntactic typology, 93-124. Amsterdam: John Benjamins. https://doi.org/10.1075/tsl.17.10dry. 
Duarte, Inês. 2003. Padrões de colocação dos pronomes clíticos. In Ana Maria Brito, Inês Duarte \& Isabel H. Faria (eds.), Gramática da língua portuguesa, 6th edn., 847-867. Lisboa: Caminho.

Duarte, Inês \& Gabriela Matos. 2000. Romance clitics and the minimalist program. In João Costa (ed.), Portuguese syntax. New comparative studies, 116-142. Oxford: Oxford University Press.

Fertig, David. 2016. Mechanisms of paradigm leveling and the role of universal preferences in morphophonological change. Diachronica 33(4). 423-460. https://doi.org/10.1075/dia. 33.4.01fer.

Fiéis, Alexandra. 2001. Interpolação em português medieval como adjunção a XP. In Actas do XVI Encontro Nacional da Associação Portuguesa de Linguística, 197-211. Lisboa: Colibri-APL.

Freitas, Maria João. 2016. A sílaba na gramática do adulto e na aquisição de língua materna. In Ana Maria Martins \& Ernestina Carrilho (eds.), Manual de linguística portuguesa, 663687. Berlin: De Gruyter. https://doi.org/10.1515/9783110368840-027.

Frota, Sonia \& Marina Vigário. 1996. On weight effects in European Portuguese. In: Paper presented at GLOW Workshop on Weight Effects, Athens.

Furtado da Cunha, Maria A. 2001. 0 modelo das motivações competidoras no domínio funcional da negação. DELTA. Documentação de Estudos em Lingüística Teórica e Aplicada 17(1). 1-30.

Galves, Charlotte. 2018. The Tycho Brahe Corpus of Historical Portuguese. Methodology and results. Linguistic Variation 18 (1) (Special issue: Romance Parsed Corpora). 49-73. https://doi.org/10.1075/lv.00004.gal.

Galves, Charlotte, Helena Britto \& Maria Clara Paixão de Sousa. 2005. The change in clitic placement from classical to modern European Portuguese: Results from the Tycho Brahe Corpus. Journal of Portuguese Linguistics 4. 39-67.

Gupton, Timothy. 2014. Preverbal subjects in Galician: Experimental data in the A vs. $A^{\prime}$ debate. Probus 26(1). 135-175. https://doi.org/10.1515/probus-2013-0002.

Harris, James \& Morris Halle. 2005. Unexpected plural inflections in Spanish: Reduplication and metathesis. Linguistic Inquiry 36(2). 195-222. https://doi.org/10.1162/0024389053710710.

Hinzelin, Marc-Olivier. 2007. Die Stellung der klitischen Objektpronomina in den romanischen Sprachen. Diachrone Perspektive und Korpusstudie zum Okzitanischen sowie zum Katalanischen und Französischen. Tübingen: Gunter Narr Verlag.

Hinzelin, Marc-Olivier. 2010. L'interpolation dans les langues romanes: Aspects diachroniques. In Maria Iliescu, Heidi Siller-Runggaldier \& Paul Danler (eds.), Actes du XXVe Congrès International de Linguistique et Philologie Romanes. Innsbruck, 3 - 8 septembre 2007, 331-339. Tübingen: Niemeyer, t. II.

Hualde, José Ignacio. 1991. On Spanish syllabification. In Héctor Campos \& Fernando MartínezGil (eds.), Current studies in Spanish linguistics, 475-493. Washington, DC: Georgetown University Press.

Kragh, Kirsten \& Lene Schøsler. 2015. Regrammation and paradigmatization: Diachronic analysis of a number of progressive periphrases in French. Journal of French Language Studies 25(2). 265-293. https://doi.org/10.1017/S0959269515000137.

Kroch, Anthony. 2001. Syntactic change. In Mark Baltin \& Chris Collins (eds.), Handbook of contemporary syntactic theory, 699-729. Oxford: Blackwell. https://doi.org/10.1002/ 9780470756416.ch22.

Laka, Itziar. 1990. Negation in syntax: On the nature of functional categories and projections. Cambridge: MIT dissertation. 
Larrivée, Pierre. 2017. Negation and polarity. In Andreas Dufter \& Elisabeth Stark (eds.), Manual of Romance morphosyntax and syntax, 449-471. Berlin: De Gruyter. https://doi.org/10. 1515/9783110377088-012.

Lightfoot, David. 2006. How new languages emerge. Cambridge: CUP.

López, Luis. 2009. A derivational syntax for information structure. Oxford: Oxford University Press. https://doi.org/10.1093/acprof:0so/9780199557400.001.0001.

Luís, Ana. 2014. On clitic attachment in Ibero-Romance. Evidence from Portuguese and Spanish. In Patrícia Amaral \& Ana Maria Carvalho (eds.), Portuguese-Spanish interfaces: Diachrony, synchrony and contact, 203-235. Amsterdam: John Benjamins. https://doi.org/10.1075/ ihll.1.11lui.

Luís, Ana \& Georg Kaiser. 2016. Clitic pronouns: Phonology, morphology, and syntax. In W. Leo Wetzels, Sergio Menuzzi \& João Costa (eds.), The handbook of Portuguese linguistics, 471486. West Sussex: John Wiley \& Sons, Inc. https://doi.org/10.1002/9781118791844.ch12. Madeira, Ana. 1992. On clitic placement in European Portuguese. In Hans van de Koot (ed.), University College London working papers in linguistics, vol. 4, 95-122. London: University College.

Magro, Catarina. 2010a. Interpolação \& Cia nos dialectos do Português Europeu. Estudos De Lingüística Galega 2. 97-119. https://doi.org/10.3309/1989-578X-10-5.

Magro, Catarina. 2010b. When corpus analysis refutes common beliefs: The case of interpolation in European Portuguese dialects. Corpus 9. 115-135.

Maiden, Martin. 1995. Evidence from the Italian dialects for the internal structure of prosodic domains. In John Charles Smith \& Martin Maiden (ed.), Linguistic theory and the Romance languages, 115-131. Amsterdam: John Benjamins. https://doi.org/10.1075/cilt.122.05mai.

Martins, Ana Maria. 1994. Clíticos na história do português. Lisboa: Faculdade de Letras da Universidade de Lisboa dissertation.

Martins, Ana Maria. 2002. The loss of IP-scrambling in Portuguese: Clause structure, word order variation and change. In David Lightfoot (ed.), Syntactic effects of morphological change, 232-248. Oxford: Oxford University Press. https://doi.org/10.1093/acprof:0so/ 9780199250691.003.0013.

Martins, Ana Maria. 2005. Clitic placement, VP-ellipsis and scrambling in Romance. In Montserrat Batllori, Maria-Lluïsa Hernanz, Carme Picallo \& Francesc Roca (eds.), Grammaticalization and parametric change, 175-193. Oxford: Oxford University Press. https://doi.org/10.1093/acprof:0so/9780199272129.003.0011.

Martins, Ana Maria. 2011a. Scrambling and information focus in old and contemporary Portuguese. Catalan Journal of Linguistics 10. 133-158.

Martins, Ana Maria. 2011b. Clíticos na história do português à luz do teatro vicentino. Estudos de Lingüística Galega 3. 83-109. https://doi.org/10.3309/1989-578X-11-5.

Martins, Ana Maria. 2014. Syntactic change in Portuguese and Spanish. Divergent and parallel patterns of linguistic splitting. In Patrícia Amaral \& Ana Maria Carvalho (eds.), PortugueseSpanish interfaces: Diachrony, synchrony and contact, 35-64. Amsterdam: John Benjamins. https://doi.org/10.1075/ihll.1.04mar.

Martins, Ana Maria. 2016. A colocação dos pronomes clíticos em sincronia e diacronia. In Ana Maria Martins \& Ernestina Carrilho (eds.), Manual de linguística portuguesa, 410-430.

Berlin: De Gruyter. https://doi.org/10.1515/9783110368840-017.

Mateus, Maia Helena \& Ernesto d'Andrade. 2000. The phonology of Portuguese. Oxford: Oxford University Press. 
Matos, Gabriela. 1999. Negative concord and the scope of negation. Catalan Working Papers in Linguistics 7. 175-190.

Miller, Philip \& Paola Monachesi. 2003. Les pronoms clitiques dans les langues romanes. In Danièle Godard \& Anne Abeillé (eds.), Les langues romanes, problèmes de la phrase simple, 53-106. Paris: CNRS.

Moravcsik, Edith A. 2010. Conflict resolution in syntactic theory. Studies in Language 34(3). 636-669.

Moravcsik, Edith A. 2014. Introduction. In Brian MacWhinney, Andrej Malchukov \& Edith Moravcsik (eds.), Competing motivations in grammar and usage, 1-14. Oxford: Oxford University Press.

Namiuti, Cristiane. 2006. Um estudo sobre o fenômeno da interpolação de constituintes na história do português. Cadernos de Estudos Lingüísticos 48(2). 171-194.

Namiuti, Cristiane. 2008. Aspectos da história gramatical do português. Interpolação, negação e mudança. Campinas: Universidade Estadual de Campinas - Instituto de Estudos da Linguagem dissertation.

Raposo, Eduardo. 2000. Clitic pronouns and verb movement. In João Costa (ed.), Portuguese syntax. New comparative studies, 266-297. Oxford: Oxford University Press.

Sánchez López, Cristina. 2017. Coordination and correlatives. In Andreas Dufter \& Elisabeth Stark (eds.), Manual of Romance morphosyntax and syntax, 647-688. Berlin: De Gruyter. https://doi.org/10.1515/9783110377088-018.

Sandalo, Filomena \& Charlotte Galves. 2013. Clitic placement and grammaticalization in Portuguese. In Christine Meklenborg Salvesen \& Hans Petter Helland (eds.), Challenging clitics, 119-134. Amsterdam: John Benjamins. https://doi.org/10.1075/la.206.05san.

Stark, Elisabeth. 2013. Clitic subjects in French text messages. Does technical change provoke and/or reveal linguistic change? In Kirsten Jeppesen Kragh \& Jan Lindschouw (eds.), Deixis and pronuns in Romance languages, 147-170. Amsterdam: John Benjamins. https://doi. org/10.1075/slcs.136.09sta.

Vigário, Marina. 2003. The prosodic word in European Portuguese. Berlin: De Gruyter.

Zanuttini, Raffaella. 2001. Sentential negation. In Mark Baltin \& Chris Collins (eds.), The handbook of contemporary syntactic theory, 511-535. Malden: Blackwell. https://doi.org/ 10.1002/9780470756416.ch16.

Zwicky, Arnold M. 1977. On clitics. Bloomington, IL: Indiana University Linguistics Club.

Zwicky, Arnold M. \& Geoffrey Pullum. 1983. Cliticization vs. inflection. English n't. Language 59(3). 502-513.

\section{Corpora}

Davies, Mark \& Michael Ferreira. 2015-2017. Corpus do Português: 1 billion words. https://www.corpusdoportugues.org/x.asp (accessed April 2019).

Corpus Informatizado do Português Medieval. https://cipm.fcsh.unl.pt//.

Foro Real (1280?) in Ferreira, José de Azevedo (ed.). 1987. Afonso X, Foro Real. Lisboa: I.N.I.C. 125-309.

Afonso X. Primeyra Partida (ca. 1350) in Ferreira, José Azevedo. 1980. Alphonse X, Primeyra Partida. Braga: INIC. 3-580. Edição digitalizada cedida pelo editor. 
Martins, A. M. (coord.). 2000-. CORDIAL-SIN: Corpus Dialectal para o Estudo da Sintaxe/Syntaxoriented Corpus of Portuguese Dialects. Lisboa: Centro de Linguística da Universidade de Lisboa. https://clul.ulisboa.pt/en/recurso/cordial-sin-syntax-oriented-corpus-portuguesedialects.

Galves, Charlotte, Aroldo Leal de Andrade \& Pablo Faria. 2017. Tycho Brahe Parsed Corpus of Historical Portuguese. http://www.tycho.iel.unicamp.br/ tycho/corpus/texts/psd.zip.

\section{$17^{\text {th }}$ century}

1614. Nicolao Agostinho. Relaçam summaria da vida do ... Senhor Dom Theotonio de Bragãça ... http://purl.pt/11490 (pages: 84-137; sequences with clitics: 293).

1625. Bertolameu Guerreiro. Jornada dos vassalos da coroa de Portugal, pera se recuperar a cidade do Salvador, na Bahya de todos os Santos, tomada pollos holandezes, a oito de Mayo de 1624. \& recuperada ao primeiro de Mayo de 1625. http://purl.pt/17352 (pages: 10-78; sequences with clitics: 460).

1640. Diogo de Santana. Relaçam verdadeira do milagroso portento, \& portentoso milagre, q[ue] aconteceo na India no Santo Crucifixo, q[ue] està no coro do observantissimo mosteiro das Freiras de S. Monica da cidade de Goa, em oito de Fevereiro de 636. \& continuou por muitos dias, tirada de outra, que fez o Reverendo P. M. Fr. Diogo de S. Anna. http://purl.pt/16740 (pages: 5-19; sequences with clitics: 155).

1641. Portugal. Cortes, Lisboa. Assento feito em cortes pelos tres estados dos Reynos de Portugal da acclamação, restituição \& juramento dos mesmos Reynos ao ... Rey Dom Joaõ o Quarto deste nome. http://purl.pt/12093 (pages: 2-27; sequences with clitics: 118).

1644. Anonymous. Relaçam em que se refere parte dos gloriosos successos, que na Provincia da Beira tiverão contra Castelhanos, as armas de S. Magestade, governadas por D. Alvaro de Abranches, seu Capitão General, nos meses de Mayo atè Dezembro de 643. (impr. Manoel da Sylva Impressor no Poço da Fotea). http://purl.pt/12510 (pages: 1-10; sequences with clitics: 168$)$.

1645. Jorge da Costa. Sermaõ do jubileo geral concedido pelo muy S. Padre Innocencio Decimo: Tratase engenhosamente como estes favores da misericordia de Roma saõ pera Portugal empenhos da declaraçaõ de sua justiça. http://purl.pt/20760 (pages: 3-22; sequences with clitics: 145).

1650. Bento Teixeira Feio. Relaçam/do naufragio/ que fizeram as naos/Sacramento, \& Nossa Senhora da Ata-/laya, vindo da India para o Reyno,/ no cabo de Boa Esperança; de/ que era Capitaõ mór Luis/ de Miranda Henriques,/ no anno de 1647. http://purl.pt/28100 (pages: 5-47; sequences with clitics: 583).

1660. Padre Antonio Vieira. Copia de huma carta para ElRey N. Senhor. Sobre as missoes do Seará, do Maranham, do Pará, \& do grande rio das Almasónas. http://purl.pt/16556 (pages: 3-20; sequences with clitics: 198).

1680. Luís Serrão Pimentel. Methodo Lusitanico de desenhar as fortificaçoens das praças regulares, \& irregulares, fortes de campanha, e outras obras pertencentes a architectura militar distribuido em duas partes operativa, e qualificativa. Ao muito alto, e poderoso Principe Dom Pedro Nosso Senhor. http://purl.pt/24485 (pages: 299-330; sequences with clitics: 250$)$. 
1686. Antonio Carvalho da Costa.Compendio geographico: distribuido em tres tratados, $o$ primeiro, da projeç̧am das espheras em plano, construcçam dos Mappas universaes, \& particulares, \& fabrica das cartas Hydrographicas: o segundo da Hydrographia dos Mares: o terceiro da descripçam Geographica das terras, com varias proposiçoens pertencentes a esta materia. http://purl.pt/13823 (pages: 96-141; sequences with clitics: 418).

1692. Vicente Barbosa C.R. Compendio da relaçam, que veyo da India o anno de 1691 ... da nova missam dos Padres Clerigos Regulares da Divina Providencia na ilha de Borneo. http:// purl.pt/12025 (pages: 2-12; sequences with clitics: 152 ).

1697. Aires de Almeyda S.J. Sermam do acto da fee que se celebrou em Coimbra no Terreiro de S. Miguel em 17. de Outubro de 1694. http://purl.pt/13488 (pages: 3-19; sequences with clitics: 139).

1735. Antonio Vieyra S.J. Cartas (Volume 1). https://digital.bbm.usp.br/handle/bbm/4527 (pages: 33-201, 401-438; sequences with clitics: 1318).

\section{$18^{\text {th }}$ century}

1701. Anonymous. Epitome da portentosa vida, e milagres de Sta. Catharina de Ricciis, Florentina, religiosa professa da Ordem do glorioso Pariarca S. Domingos; novamente canonizada pelo N. SS. P. Benedicto XIV. e extrahida dos monumentos da Sagrada Congregaçaõ de Ritos. http://purl.pt/346 (pages: 1-15; sequences with clitics: 199).

1714. Anonymous. Relaçam da campanha de Alem-Tejo no Outono de 1712, com o Diario do sitio, \& gloriosa defensa da praça de Campo Mayor, recopiladas memorias dos Generaes. http://purl.pt/26483. Miguel Manescal (impr.) (pages: 12-52; sequences with clitics: 373 ).

1736. João Manoel. Vaticinio exposto, confirmado, e defendido: exposto á Universidade de Coimbra na solenne acçaõ de graças, que celebrou congregada em prestito no dia 4. de Janeiro de 1735. pelo felicissimo nascimento da Serenissima Princeza da Beira: confirmado, e defendido na occaziaõ do segundo parto da Serenissima Princeza do Brazil ... http://purl.pt/6819 (pages: 6-47; sequences with clitics: 282).

1748. Anonymous. Relação do formidavel, e lastimoso terremoto succedido no Reino de Valença no dia 23 de Março deste presente anno de 1748 pelas 6. horas, e tres quartos da manhã, e dos horrorosos estragos, e lamentaveis ruinas, que tem padecido a cidade de Valença, capital daquelle Reino, e mais lugares circumvisinhos, conforme as noticias communicadas até o dia 27 do mesmo mez ao Capitaõ General, Arcebispo, e Intendente, e as que sucessivamente vaõ chegando á Corte de Madrid, de onde se communicaraõ a esta de Lisboa. http://purl.pt/347. Francisco Luís Ameno (impr.) (pages: 2-8; sequences with clitics: 77$)$.

1749. Anonymous. Compromisso da Irmandade da Gloriosa Virgem e Martir Santa Cecilia ordenado pellos Professores da Arte da Musica em o anno de 1749. http://purl.pt/24981 (pages: 6-42; sequences with clitics: 251).

1758. Luís António Verney. Resposta/ as Reflexoens,/ que o R. P. M. Fr. Arsenio da Piedade Capu-/cho fez ao livro intitulado:/ Verdadeiro metodo de estudar./ Escrita por outro religioso da dita Provincia para de-/zagravo da mesma religiam, e da Nasam. http://purl. pt/24753 (pages: 3-39; sequences with clitics: 402).

1758. Anonymous. Noticia certa das grandes vitorias que os austriacos alcançaram contra os prussianos na Silezia. http://purl.pt/21751 (pages: 1-8; sequences with clitics: 37 ). 
1758. Anonymous. Noticia da grande vitoria, alcançada pelos prussianos contra russianos. http://purl.pt/20902. Joseph Filippe (impr.). (pages: 1-8; sequences with clitics: 56).

1759. Anonymous. Noticia da Batalha Alcançada pelos Francezes contra o Exercito Aliado de Hanover no dia 13. de Abril defte prefente anno, junto ao lugar de Bergen. http://purl.pt/ 21755 Antonio Vicente da Silva (impr.) (pages: 1-8; sequences with clitics: 72).

1759. Anonymous. Relação da batalha alcançada pelos hespanhoes contra os mouros. Diario do avance, que derão os Turcos à Praça de Orão desde o dia 11 de março até 4 de abril deste presente anno de 1759. http://purl.pt/21757 Ignacio Nogueira Xisto (impr.) (pages: 2-8; sequences with clitics: 45).

1759. Anonymous. Relação marcial do plausivel, e affortunado successo, que nas partes da India tiveraõ as armas portuguezas contra o Bonsulo nosso inimigo em o conflicto com elle havido em o dia nove de Mayo do anno passado de 1758 Francisco Borges de Sousa (impr.). http://purl.pt/23684 (pages: 1-8; sequences with clitics 80).

1759. Anonymous. Relação verdadeira, e curiosa da admiravel batalha, que alcançaram os austriacos contra os prussianos. Em que se dá tambem a lér a grande perda que os mesmos prussianos tiveraõ, em outro combate com as armas do Imperio. Ignacio Nogueira Xisto (impr.). http://purl.pt/21754 (pages: 1-8; sequences with clitics 56).

1759. Manoel Joseph de Paiva. Infermidades da Lingua, e Arte que a ensina a emmudecer para melhorar. Author Sylvestre Silverio da Silveira e Silva. Invoca-se a proteçam do glorioso Santo Antonio de Lisboa. http://purl.pt/29106 (pages: 75-108; sequences with clitics: 500).

1759. Pedro Norberto de Aucourt e Padilha. Raridades da natureza, e da arte, divididas pelos quatro elementos. http://purl.pt/13915 (pages: 39-504; sequences with clitics: 2073).

1759. António José da Silva. Theatro comico portuguez, ou collecçaõ das operas portuguezas, que se representaraõ na Casa do Theatro publico do Bairro Alto de Lisboa. Tomo $1 \mathrm{http}: / /$ purl.pt/12184 (pages: 81-136; sequences with clitics: 425).

1761. Irmaõ Amador do Dezengano. Espelho critico, no qual claramente se vem alguns defeitos das mulheres, fabricado na loja da verdade pelo irmaõ Amador do Dezengano, que póde servir de estimulo para a reforma dos mesmos defeitos. http://purl.pt/22744 (pages: 3-11; sequences with clitics: 73).

1776. Anonymous. Plano dos Estudos para a Província dos Religiosos Trinitarios de Portugal ordenado segundo o methodo dos Novissimos Estatutos da Universidade de Coimbra do anno de 1772, e já publicados na Lipsia em o anno de 1774. http://purl.pt/28644 (pages: 9-40; sequences with clitics: 237 ).

1777. D. Fr. Manoel do Cenaculo Villas-Boas, Bispo de Béja. Pastoral pela qual admoesta os seus diocesanos. http://purl.pt/14350 (pages: 1-15; sequences with clitics: 108).

1785. José Anastácio da Silva e Fonseca. Conclusões de rhetorica, e poetica: Presidente D. Luiz da Senhora do Carmo, ... Defende José Anastacio da Silva e Fonseca. Aos 13 de Julho 1785. http://purl.pt/16610 (pages: 3-21; sequences with clitics: 220).

1791. Francisco José de Almeida. Tratado da educação fisica dos meninos. http://purl.pt/6378 (pages: 11-51; sequences with clitics: 321). 


\section{$19^{\text {th }}$ century}

1800. Vicente Coelho de Seabra Silva Telles. Memoria sobre os prejuisos causados pelas sepulturas dos cadaveres nos templos, e methodo de os prevenir. http://purl.pt/11500 (pages: 9-46; sequences with clitics: 230).

1804-1810. Theatro de Manuel de Figueiredo. Tomo I http://purl.pt/11977 (pages: 49-229; sequences with clitics: 745$)$.

1809. Anonymous. Carta que escreve hum militar portuguez. http://purl.pt/14932 (pages: 3-23; sequences with clitics: 287 ).

1810. José Accursio das Neves. Historia geral da invasão dos francezes em Portugal e da restauração deste reino. Tomo $1 \mathrm{http://purl.pt/12098} \mathrm{(pages:} \mathrm{212-307;} \mathrm{sequences} \mathrm{with}$ clitics: 470).

1820. Xavier de Quadros Bernardino. Ao dominante patriotismo dos portugueses. http://purl. pt/16645 (pages: 1-8; sequences with clitics: 30 ).

1820. Anonymous. Os officiaes da cidade do Porto aos governadores de Lisboa. http://purl.pt/ 16695 (pages: 3-19; sequences with clitics: 152).

1820. Joaquim José da Costa de Macedo. Projecto de regimento das cortes portuguezas. http:// purl.pt/5869 (pages: 4-75; sequences with clitics: 593 ).

1820. Marino Miguel Franzini. Reflexões sobre o actual regulamento do exército de Portugal publicado em 1816; ou analyse dos artigos essencialmente defeituosos e nocivos à nação. Com o projecto de hum plano de organisação para o mesmo exercito, illustradas com mappas do estado da povoação do Reino, e sua classificação segundo as idades, sexo, estado, e profissões, enviado para a Côrte do Rio de Janeiro em Novembro de 1816. http:// purl.pt/17391 (pages: 3-32; sequences with clitics: 181).

1823. Luís da Silva Mousinho de Albuquerque. Ideas sobre o estabelecimento da instrucção publica. http://purl.pt/6412 (pages: 3-40; sequences with clitics: 170).

1829. Inácio Caetano Xavier. Relação das operações militares da expedição. http://purl.pt/ 6593 (pages: 3-42; sequences with clitics: 335).

1832. Guilherme Walton. A expedição de Dom Pedro ou a neutralidade em disfarce. http://purl. pt/6673 (pages: 1-48; sequences with clitics: 374 ).

1834. A.J.F.G. Horrorosa mortandade feita em todos os presos políticos que se achavão no Castello de Extremoz no infausto dia 27 de Julho de 1833, com todas as circunstancias que acompanhárâo tão inaudita catastrofe, e nomes dos assassinos, e presos assassinados. http://purl.pt/31011 (pages: 7-24; sequences with clitics: 130).

1836. O correio das damas: jornal de litteratura e de modas. T. 1, n- 1 (1 Jan. 1836) pages: 3-10; T. 2, no 2 (15 Jan. 1836) pages: 1-8. http://purl.pt/14346 (sequences with clitics: 198).

1848. $O$ republicano. - N. 3 (1848), N. 4 (1848), N. 5 (1848). http://purl.pt/14891 (pages: 9-20; sequences with clitics: 229$)$.

1848. A fraternidade. - N. 1 (1848)-n. 2 (1848). http://purl.pt/14892 (pages: 1-8; sequences with clitics: 181).

1858. Alexandre Herculano. Carta aos leitores do circulo eleitoral de Cintra. http://purl.pt/1682 (pages: 2-11; sequences with clitics: 132). 